\title{
National Weatherization Assistance Program Impact Evaluation: Energy Impacts for Large Multifamily Buildings
}

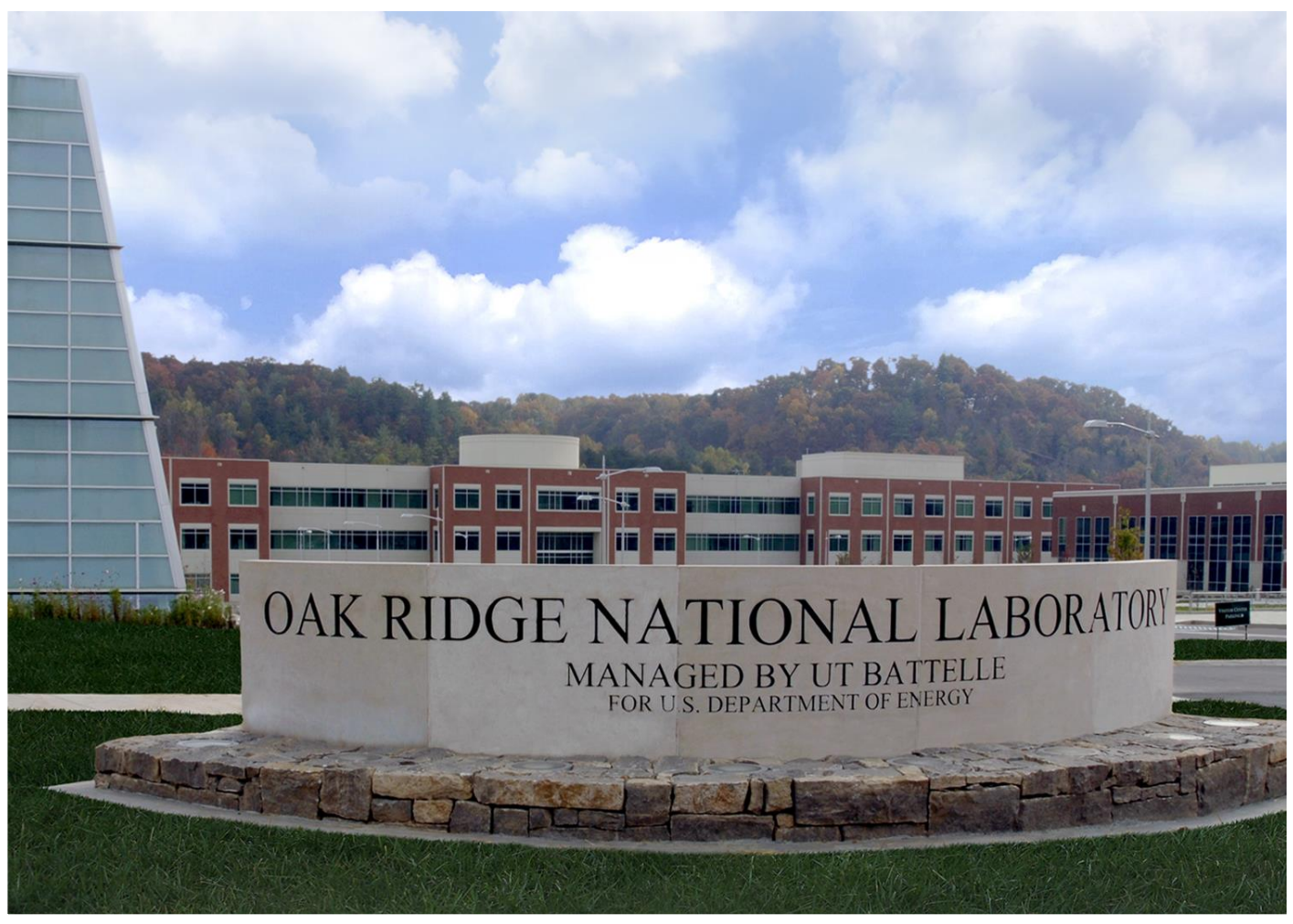

Michael Blasnik

Greg Dalhoff

David Carroll

Ferit Ucar

September 2014 


\section{DOCUMENT AVAILABILITY}

Reports produced after January 1, 1996, are generally available free via US Department of Energy (DOE) SciTech Connect.

Website http://www.osti.gov/scitech/

Reports produced before January 1, 1996, may be purchased by members of the public from the following source:

National Technical Information Service

5285 Port Royal Road

Springfield, VA 22161

Telephone 703-605-6000 (1-800-553-6847)

TDD 703-487-4639

Fax 703-605-6900

E-mail info@ntis.gov

Website http://www.ntis.gov/help/ordermethods.aspx

Reports are available to DOE employees, DOE contractors, Energy Technology Data Exchange representatives, and International Nuclear Information System representatives from the following source:

Office of Scientific and Technical Information

PO Box 62

Oak Ridge, TN 37831

Telephone 865-576-8401

Fax 865-576-5728

E-mail reports@osti.gov

Website http://www.osti.gov/contact.html

This report was prepared as an account of work sponsored by an agency of the United States Government. Neither the United States Government nor any agency thereof, nor any of their employees, makes any warranty, express or implied, or assumes any legal liability or responsibility for the accuracy, completeness, or usefulness of any information, apparatus, product, or process disclosed, or represents that its use would not infringe privately owned rights. Reference herein to any specific commercial product, process, or service by trade name, trademark, manufacturer, or otherwise, does not necessarily constitute or imply its endorsement, recommendation, or favoring by the United States Government or any agency thereof. The views and opinions of authors expressed herein do not necessarily state or reflect those of the United States Government or any agency thereof.

ORNL Principal Investigator

Dr. Bruce Tonn

Evaluation Team Task Manager

Michael Blasnik 
Environmental Sciences Division

\title{
NATIONAL WEATHERIZATION ASSISTANCE PROGRAM IMPACT EVALUATION: \\ ENERGY IMPACTS FOR LARGE MULTIFAMILY BUILDINGS
}

\author{
Michael Blasnik, Blasnik \& Associates \\ Greg Dalhoff, Dalhoff \& Associates \\ David Carroll, APPRISE \\ Ferit Ucar, APPRISE
}

September 2014

\author{
Prepared by \\ OAK RIDGE NATIONAL LABORATORY \\ Oak Ridge, Tennessee 37831-6283 \\ managed by \\ UT-BATTELLE, LLC \\ for the \\ US DEPARTMENT OF ENERGY \\ under contract DE-AC05-00OR22725
}





\section{CONTENTS}

Page

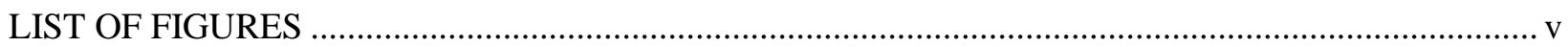

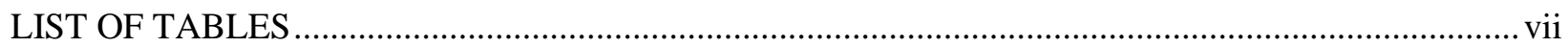

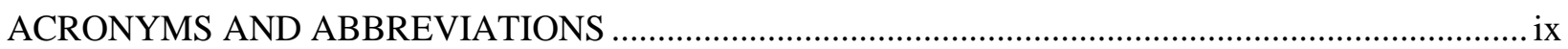

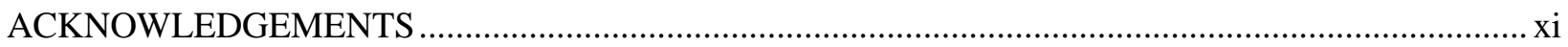

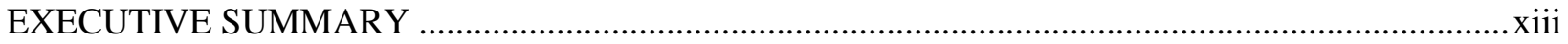

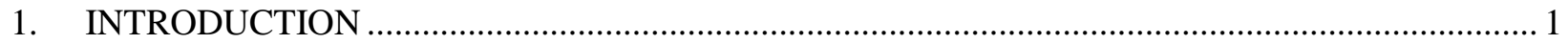

1.1 NATIONAL WEATHERIZATION ASSISTANCE PROGRAM EVALUATION

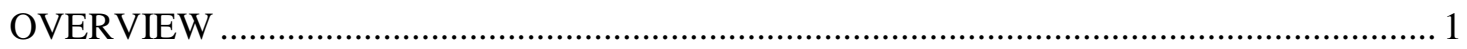

1.2 LARGE MULTIFAMILY BUILDING STUDY OVERVIEW ..................................... 2

1.2.1 National Sample of Weatherized Housing Units ...................................................... 2

1.2.2 New York City Large Multifamily Building Study ............................................... 3

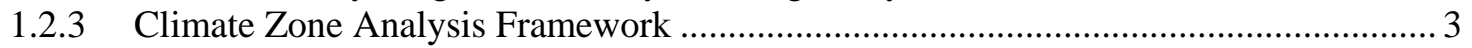

1.3 ORGANIZATION OF THE LARGE MULTIFAMILY IMPACT REPORT …....................... 4

2. OVERVIEW OF DATA COLLECTION METHODOLOGY …............................................... 5

2.1 SUBGRANTEE AND BUILDING/CLIENT SAMPLE - NATIONAL SAMPLE .................. 5

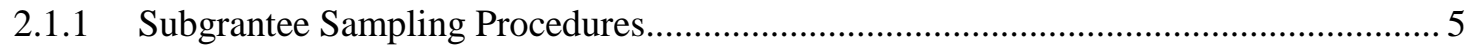

2.1.2 Building/Client Sampling Procedures.................................................................. 5

2.1.3 Subgrantee and Client Sampling Statistics and Response Rates ................................. 6

2.2 SUBGRANTEE DATA COLLECTION - NATIONAL SAMPLE ..................................... 6

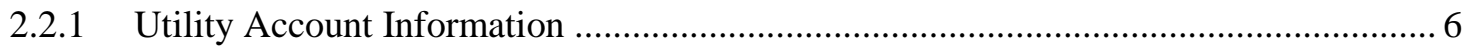

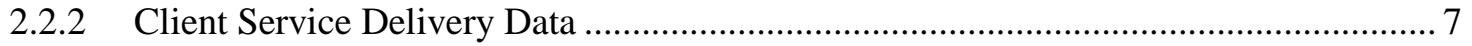

2.3 NATURAL GAS AND ELECTRIC USAGE DATA COLLECTION - NATIONAL

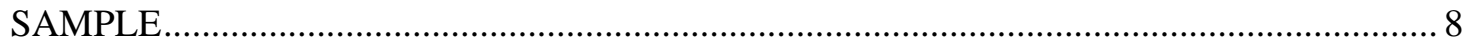

2.4 NEW YORK CITY LARGE MULTIFAMILY STUDY …............................................... 9

3. PRODUCTION, BUILDING CHARACTERISTICS, AND INSTALLED MEASURES ................ 11

3.1 WAP PRODUCTION - ALL HOUSING UNIT TYPES ............................................... 11

3.2 WAP PRODUCTION - LARGE MULTIFAMILY BUILDINGS …................................ 13

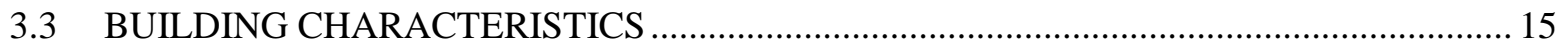

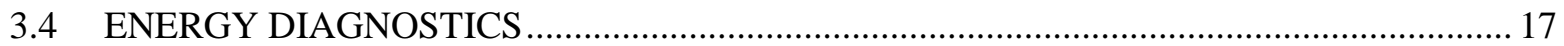

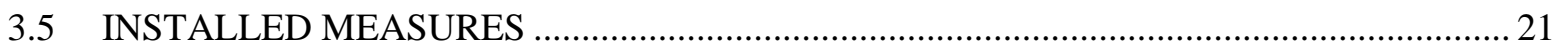

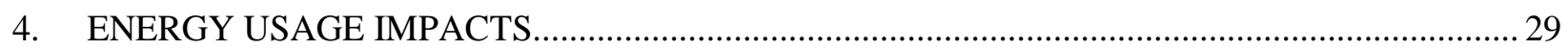

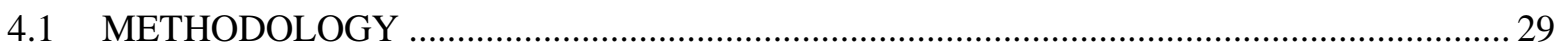

4.2 ENERGY SAVINGS - NON-NYC NATIONAL SAMPLE ............................................... 30

4.3 ENERGY SAVING - NYC SAMPLE ............................................................................... 31

4.4 PROJECTED PY 2008 ENERGY SAVINGS FOR LARGE MULTIFAMILY

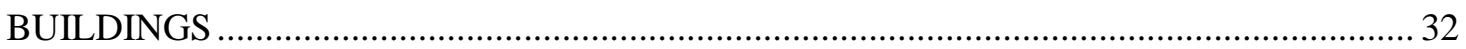

4.4.1 Projected Energy Savings for The National Non-NYC Sample ................................. 32

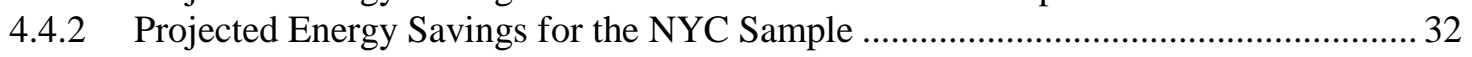

5. COST SAVINGS, MEASURE COSTS, AND COST-EFFECTIVENESS …................................ 35

5.1 COST SAVINGS AND COST-EFFECTIVENESS FOR NON-NYC SAMPLE ................... 35

5.2 COST SAVINGS AND COST-EFFECTIVENESS FOR NYC SAMPLE ........................... 35 



\section{LIST OF FIGURES}

Figure

Page

Figure 1.1. Climate Zone Map for the PY 2008 Evaluation ............................................................ 4 



\section{LIST OF TABLES}

Table

Page

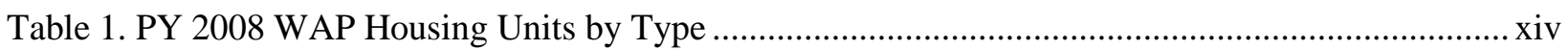

Table 2. PY 2008 WAP Housing Units in Large Multifamily Buildings ................................................

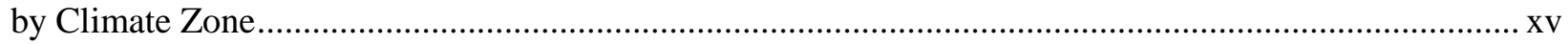

Table 3. Characteristics of Large Multifamily Buildings Served by WAP in PY 2008 ..........................xv

Table 4. Major Measure Installation Rates for Large Multifamily Buildings Served .............................. xvi

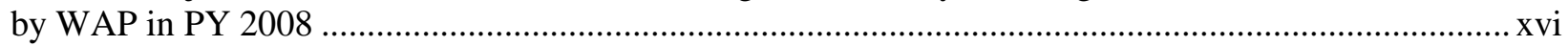

Table 5. PY 2008 WAP Energy Impacts for Large Multifamily Buildings - Non-NYC Gross and

Net Gas Savings (therms/unit/year) for Natural Gas Main Heat ......................................... xvii

Table 6. PY 2008 WAP Energy Impacts for Large Multifamily Buildings - Non-NYC Gross and

Net Electric Savings (kWh/unit/year) for Natural Gas Main Heat .......................................xvii

Table 7. PY 2008 WAP Energy Impacts for Large Multifamily Buildings - Non-NYC Gross and

Net Electric Savings (kWh/unit/year) for Electric Main Heat ..........................................xvii

Table 8. PY 2007-2009 WAP Energy Impacts for Large Multifamily Buildings - NYC Gross Fuel

Savings (therms/unit/year) ...............................................................................................

Table 9. PY 2007-2009 WAP Energy Impacts for Large Multifamily Buildings - NYC Gross

Electric Savings (kWh/unit/year) ...................................................................................

Table 10. PY 2008 WAP Energy Impacts for Large Multifamily Buildings - NYC Gross Savings

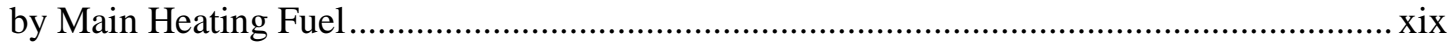

Table 11. PY 2008 WAP Impacts for Large Multifamily Buildings - NYC.......................................... Xx

Table 12. PY 2008 WAP Impacts for Large Multifamily Buildings - NYC.......................................... Xx

Energy Cost Savings, Efficiency Measure Costs, and Cost-Effectiveness by Main Heating Fuel

Program Expenditures - All Funding Sources ..................................................................... xx

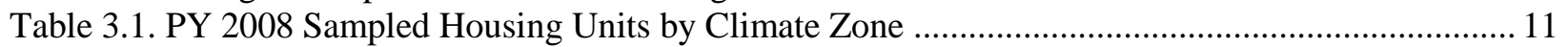

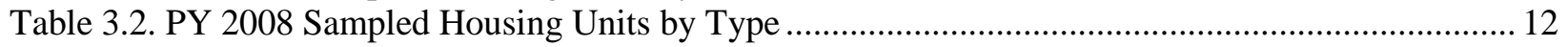

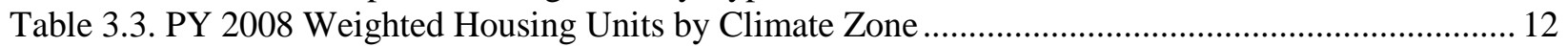

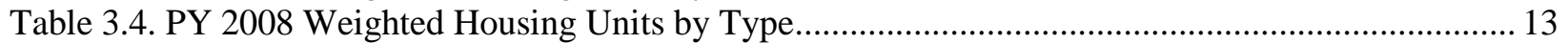

Table 3.5. PY 2008 Weighted Housing Units by Climate Zone and Housing Unit Type ......................... 13

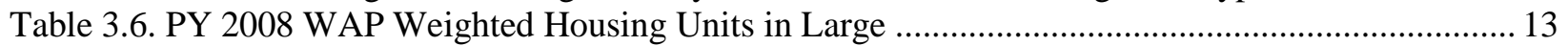

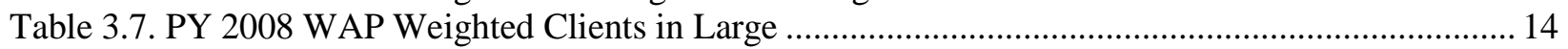

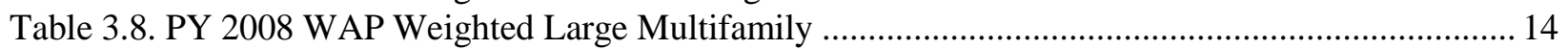

Table 3.9. PY 2008 WAP Weighted Large Multifamily ........................................................................ 14

Table 3.10a. PY 2008 Large Multifamily Buildings Housing Unit Characteristics by Climate Zone ...... 15

Table 3.10b. PY 2008 Large Multifamily Buildings Housing Unit Characteristics by Number of

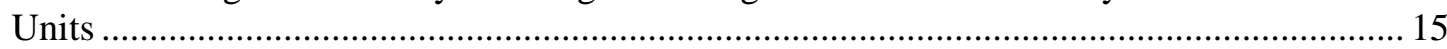

Table 3.11a. PY 2008 Large Multifamily Buildings Heating and Cooling System Characteristics by

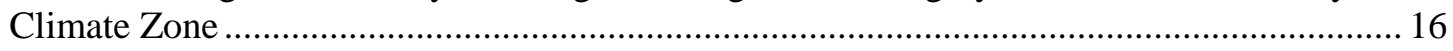

Table 3.11b. PY 2008 Large Multifamily Buildings Heating and Cooling System Characteristics by

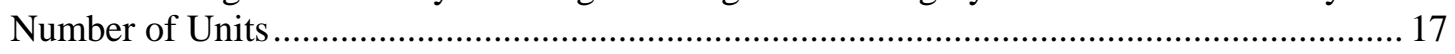

Table 3.12a. PY 2008 Clients in Large Multifamily Buildings Diagnostics Approach by Climate Zone.

Table 3.12b. PY 2008 Clients in Large Multifamily Buildings Diagnostics Approach by Number of Units

Table 3.13a. PY 2008 Clients in Large Multifamily Buildings Air Leakage and Insulation

Diagnostics by Climate Zone

Table 3.13b. PY 2008 Clients in Large Multifamily Buildings Air Leakage and Insulation

Diagnostics by Number of Units 
Table 3.14a. PY 2008 Clients in Large Multifamily Buildings Equipment Diagnostics by Climate Zone

Table 3.14b. PY 2008 Clients in Large Multifamily Buildings Equipment Diagnostics by Number of Units

Table 3.15a. PY 2008 Clients in Large Multifamily Buildings Air Sealing and Shell Measures by Climate Zone

Table 3.15b. PY 2008 Clients in Large Multifamily Buildings Air Sealing and Shell Measures by Number of Units

Table 3.16a. PY 2008 Clients in Large Multifamily Buildings Heating and Water Heating Equipment Measures by Climate Zone 24

Table 3.16b. PY 2008 Clients in Large Multifamily Buildings Heating and Water Heating Equipment Measures by Number of Units 25

Table 3.17a. PY 2008 Clients in Large Multifamily Buildings Door and Window Measures by Climate Zone 26

Table 3.17b. PY 2008 Clients in Large Multifamily Buildings Door and Window Measures by Number of Units

Table 3.18a. PY 2008 Clients in Large Multifamily Buildings Electric Base Load Equipment Measures by Climate Zone 28

Table 3.18b. PY 2008 Clients in Large Multifamily Buildings Electric Base Load Equipment Measures by Number of Units. 28

Table 4.1. PY 2008 WAP Energy Impacts for Large Multifamily Buildings - Non-NYC Sample Gross and Net Gas Savings Per Unit for Gas Main Heat (therms/unit/year) ... 30

Table 4.2. PY 2008 WAP Energy Impacts for Large Multifamily Buildings - Non-NYC Sample Gross and Net Electric Savings Per Unit for Natural Gas Main Heat (kWh/unit/year) .......... 31

Table 4.3. PY 2008 WAP Energy Impacts for Large Multifamily Buildings - Non-NYC Sample Gross Electric Savings Per Unit for Electric Main Heat (kWh/unit/year).... 31

Table 4.4. PY 2007-2009 WAP Energy Impacts for Large Multifamily Buildings - NYC Sample Gross Gas and Oil Savings (therms/unit/year)

Table 4.5. PY 2007-2009 WAP Energy Impacts for Large Multifamily Buildings - NYC Sample Gross Electric Savings (kWh/unit/year)....

Table 4.6. PY 2008 WAP Energy Impacts for Large Multifamily Buildings - NYC Sample Projected Fuel and Electric Savings per Unit, by Heating Fuel 33

Table 5.1. Spending on Large Multifamily Buildings for PYs 2007-2009 - NYC Sample ....................... 36

Table 5.2. Spending on Large Multifamily Buildings for PYs 2007-2009 - NYC Sample ...................... 36

Table 5.3a. PY 2008 WAP Impacts for Large Multifamily Buildings - NYC Sample Energy Cost Savings, Efficiency Measure Costs, and Cost-Effectiveness ................................................ 37

Table 5.3b. PY 2008 WAP Impacts for Large Multifamily Buildings - NYC Sample Energy Cost Savings, Efficiency Measure Costs, and Cost-Effectiveness .................................................. 38

Table 5.3c. PY 2008 WAP Impacts for Large Multifamily Buildings - NYC Sample Energy Cost Savings, Efficiency Measure Costs, and Cost-Effectiveness .38 


\section{ACRONYMS AND ABBREVIATIONS}

AC
ANACOVA
BTU
CDD
CFR
DOE
EIA
ECM
FY
HDD
IR
kWh
LIHEAP
LMF
MMBtu
NCDC
NYC
ORNL
PRISM
PY
SFSB
SIR
SOW
SSE
Therms
TIPS
WAP

Air Conditioning

Analysis of Covariance

British Thermal Unit

Cooling Degree Days

Code of Federal Regulations

U.S. Department of Energy

U.S. Energy Information Administration

Energy Conservation Measure

Fiscal Year

Heating Degree Days

Infrared

Kilowatt Hour

Low Income Home Energy Assistance Program

Large Multifamily

Mean Million British Thermal Units

National Climatic Data Center

New York City

Oak Ridge National Laboratory

Princeton Scorekeeping Method

Program Year

Single Family Site Built

Savings to Investment Ratio

Scope of Work

Steady State Efficiency

100,000 British Thermal Units

Targeted Investment Protocol System

Weatherization Assistance Program 



\title{
ACKNOWLEDGEMENTS
}

The work presented in this report was funded by the U.S. Department of Energy's (DOE) Office of Weatherization and Intergovernmental Programs (OWIP).

The purpose of this report is to disseminate the findings from an analysis of the energy savings, cost savings, and cost-effectiveness for large multifamily buildings treated by DOE's Weatherization Assistance Program (WAP) during Program Years (PY) 2007, 2008, and 2009.

The original design for this research was developed by staff from the Oak Ridge National Laboratory (ORNL) as one component of the National Evaluation of the Weatherization Assistance Program. (National Evaluation of the Weatherization Assistance Program: Preliminary Evaluation Plan for Program Year 2006 - ORNL/CON-498). As part of the evaluation plan development, the design team consulted with and received feedback from the Network Planning Committee, 41 individuals from the weatherization network.

ORNL contracted with the research team of APPRISE Incorporated, the Energy Center of Wisconsin, Michael Blasnik and Associates, and Dalhoff Associates LLC to conduct the National Evaluation. The evaluation team implemented the specified data collection and analysis activities to develop statistics for this report.

\section{Grantee and Subgrantee Data Collection}

The Energy Center of Wisconsin (ECW) collected information on program funding and clients served from 51 grantees and 879 subgrantees, as well as detailed information on weatherization jobs from 379 subgrantees. The cooperation and contributions made by the WAP program grantees and subgrantees were essential to the completion of the study. The ECW team responsible for grantee and subgrantee data collection for the study included:

\author{
The Energy Center of Wisconsin \\ Ingo Bensch \\ Claire Cowan \\ Sharon Flores \\ LaShanta Goodwin \\ Ashleigh Keene \\ Steve Kihm \\ Karen Koski \\ Jeannette LeZaks \\ Melanie Lord \\ Andy Mendyk \\ Scott Pigg \\ Benjamin Rickelman \\ Jaimie Rule \\ Nick Sayen \\ Cheryl Schmidt \\ Erin Vallicelli
}




\section{Energy Supplier Data Collection}

APPRISE collected information on electric and gas usage data from 727 electric companies and 265 gas companies. The cooperation and contributions made by the electric and gas companies were essential to the completion of the study. The APPRISE staff responsible for the electric and gas company data collection and analysis for the PY 2008 study included:

James Over

Lisa Courtney

James Devlin

Arlene Shipley

Camille D'Andrea

Michael Brach

Chris Miller

Michael Fossel

Hannah Walker

Anne Worth

David Slayback

Matt Swartz

\section{New York City Large Multifamily Building Study}

APPRISE conducted a special study of large multifamily buildings in the New York City (NYC) area weatherized during PYs 2007, 2008, and 2009. The study collected information from the 16 NYC WAP subgrantees, two NYC electric and gas utilities, and $17 \mathrm{NYC}$ fuel oil vendors. The cooperation and contributions made by the weatherization agencies, the electric and gas companies, and the fuel oil vendors were essential to the completion of the study. The APPRISE staff responsible for the NYC Multifamily study data collection included:

Su Wang

Lisa Courtney

Kathy Davis

Camille D'Andrea

Carlos Salguero

Tim Lenahan

Russ Shaber

Finally, we would like to acknowledge the assistance and guidance of the Oak Ridge National Laboratory, Department of Energy Project Officers, and Department of Energy Headquarters Staff.

Michael Blasnik

Greg Dalhoff

David Carroll 


\section{EXECUTIVE SUMMARY}

The purpose of this report is to disseminate the findings from an analysis of the energy savings, cost savings, and cost-effectiveness for large multifamily buildings (i.e., buildings with 5 or more housing units) treated by U.S. Department of Energy's (DOE) Weatherization Assistance Program (WAP) during Program Years (PY) 2007, 2008, and 2009. The main focus of this study is on PY 2008. The analysis characterizes the population of large multifamily buildings served by the program, estimates the gross change in energy usage for treated buildings and housing units, makes projections for the first year and longer-term cost savings, and assesses the cost-effectiveness of the program in terms of direct energy benefits.

This is one of five energy impact reports developed for the National WAP Evaluation for PY 2008. The full set of reports covers all housing types (single family, mobile homes, and multifamily buildings) and summarizes program performance in terms of energy and nonenergy benefits. The reports give policymakers detailed information on program performance for each building type, as well as overall program performance.

\section{Background}

WAP was created by Congress in 1976 under Title IV of the Energy Conservation and Production Act. The purpose and scope of the program as currently stated in the Code of Federal Regulations (CFR) 10 CFR 440.1 is "to increase the energy efficiency of dwellings owned or occupied by low-income persons, reduce their total residential energy expenditures, and improve their health and safety, especially lowincome persons who are particularly vulnerable such as the elderly, persons with disabilities, families with children, high residential energy users, and households with high energy burden." (Code of Federal Regulations, 2011)

At the request of DOE, Oak Ridge National Laboratory (ORNL) developed a comprehensive plan for a national evaluation of WAP that was published in 2007. DOE furnished funding to ORNL in 2009 for the evaluation for PYs 2007 and 2008, with a particular emphasis on PY 2008. The Scope of Work (SOW) for the evaluation includes the following components.

- Impact Assessment - Characterization of the weatherization network and low-income households, measurement and monetization of the energy and nonenergy impacts of the program, and assessment of the factors associated with higher levels of energy savings, cost savings, and cost-effectiveness.

- Process Assessment - Direct observation of how the weatherization network delivers services, assessment of how service delivery compares to national standards, and documentation of how weatherization staff and clients perceive service delivery.

- Special Technical Studies - Examination of the performance of the program with respect to technical issues such as air sealing, duct sealing, furnace efficiency, and refrigerators.

- Synthesis Study - Synthesis of the findings to assess the program's success in meeting its goals and identify key areas for program enhancement.

This analysis of energy impacts for large multifamily buildings is part of the Impact Assessment. 


\section{Study Overview}

This study collected information on the large multifamily buildings served by the program and measured program impacts. The study procedures included:

- Development of a representative sample of buildings served by the program using data from DOE, grantees, and subgrantees.

- Collection of information from subgrantees on building characteristics, diagnostic tests conducted, installed measures, and measures costs for sampled buildings.

- Collection of energy usage information from energy suppliers.

- Statistical analysis of pre- and-post-weatherization energy usage to develop estimates of the energy impacts associated with service delivery.

- Projection of measure lifetimes and energy costs to estimate cost savings and program costeffectiveness.

This report summarizes the study findings with respect to building characteristics, installed program measures, estimated energy savings, and program cost-effectiveness.

\section{Program Characterization}

The evaluation team collected information on the buildings served by the program and the services delivered by the program. PY 2008 program production statistics were collected from the Department of Energy and WAP grantees (i.e., states). Detailed information about the buildings served by the program and the services delivered to those buildings was supplied by subgrantees (i.e., local agencies).

WAP serves low-income households in all types of housing units and in all parts of the country. According to DOE statistics, the network of WAP-funded subgrantees served 97,965 housing units in PY 2008 with DOE funding. Table 1 shows the distribution of treated units by housing unit type. About 18 percent of the treated housing units were categorized as units in large multifamily buildings. Table 2 shows the distribution of treated large multifamily buildings by Climate Zone; almost 60 percent of the treated units in large multifamily buildings in PY 2008 were in the Cold Climate Zone. The top three states - New York, Wisconsin, and California - were responsible for 62 percent of all large multifamily jobs in PY 2008.

Table 1. PY 2008 WAP Housing Units by Type

\begin{tabular}{lcc} 
Housing Unit Type & $\begin{array}{c}\text { PY 2008 Weighted } \\
\text { Count of Units }\end{array}$ & $\begin{array}{c}\text { Percent of PY 2008 } \\
\text { Units }\end{array}$ \\
\hline Single Family Site Built & 57,518 & $59 \%$ \\
Single Family Mobile Home & 17,754 & $18 \%$ \\
Small Multifamily (2-4 Units) & 5,317 & $5 \%$ \\
Large Multifamily (5+ Units) & 17,376 & $18 \%$ \\
\hline TOTAL & 97,965 & $100 \%$ \\
\hline
\end{tabular}


Table 2. PY 2008 WAP Housing Units in Large Multifamily Buildings by Climate Zone

\begin{tabular}{lcc} 
Climate Zone & PY 2008 Units & Percent of PY 2008 Units \\
\hline Very Cold Climate & 3,423 & $20 \%$ \\
Cold Climate & 10,125 & $58 \%$ \\
Moderate Climate & 1,301 & $8 \%$ \\
Hot/Humid Climate & 418 & $2 \%$ \\
Hot/Dry Climate & 2,109 & $12 \%$ \\
\hline TOTAL & 17,376 & $100 \%$ \\
\hline
\end{tabular}

Table 3 shows how treated large multifamily buildings varied with respect to a number of important building characteristics. Most units used natural gas as their main space heating fuel and their water heating fuel. The next most common configuration was buildings with fuel oil space heating and water heating. Some buildings had electric space heat, with room heaters (e.g. baseboard heaters) and electric water heat. Supplemental heat was reported for relatively few housing units.

Table 3. Characteristics of Large Multifamily Buildings Served by WAP in PY 2008

\begin{tabular}{lccc} 
Characteristic & & \\
\hline Number of Units & 5-9 Units $=22 \%$ & $10-24$ Units $=20 \%$ & 25 Units or More $=58 \%$ \\
Year Built & Pre $1940=27 \%$ & $1940-1969=24 \%$ & 1970 or Later $=49 \%$ \\
Space Heating Fuel & Gas $=71 \%$ & Electric $=10 \%$ & Fuel Oil $=19 \%$ \\
Heating System & Central $=84 \%$ & Room $=14 \%$ & Other $=2 \%$ \\
Supplemental Heat & Electric $=5 \%$ & Wood $=0 \%$ & Other $=7 \%$ \\
Water Heating Fuel & Natural Gas $=68 \%$ & Electric $=11 \%$ & Fuel Oil $=21 \%$ \\
\hline
\end{tabular}

The WAP program conducts extensive testing of buildings, both to identify cost-effective energy saving opportunities and to ensure that equipment is operating safely. However, because large multifamily buildings vary so much in terms of configuration, heating and water heating systems, and opportunities, there is more variation in terms of the types of diagnostic tests that need to be conducted and the audit tools that should be used.

- Equipment Efficiency - Because the heating and water heating equipment are addressing such large volumes of space and/or water, there are substantial potential gains from improving inefficient systems. In the largest buildings, close to 80 percent of systems are tested, compared to only 60 percent of heating equipment and 50 percent of water heating equipment in single family homes.

- Infiltration Rates - At the other end of the spectrum, it is difficult to conduct pressure testing in larger multifamily buildings. While pressure testing was reported for almost 90 percent of single family homes, it was only reported for only 41 percent of buildings with 5-9 units and only 8 percent of buildings with 25 or more units. 
- Audit Tools - For large multifamily buildings (25+ housing units) with building-level heating equipment, most subgrantees used the EA-QUIP or TREAT audit. For multifamily buildings with 10 to 25 units, priority lists were the most common measure selection procedure identified by subgrantees, but many subgrantees used the EA-QUIP or TREAT software. For multifamily buildings with 5 to 9 units, most subgrantees reported using a priority list.

After testing, WAP subgrantees install a comprehensive set of measures matched to the needs of each building. Table 4 compares the rate at which the major measures were installed in single family homes and large multifamily buildings during PY 2008. It shows that, nationally, major equipment measures (e.g., furnaces, water heaters, and refrigerators) were installed in large multifamily buildings at a higher rate than for single family homes. But, major shell measures (e.g., bypass air sealing, attic insulation, and wall insulation) were installed at much lower rates than for single family homes.

\section{Table 4. Major Measure Installation Rates for Large Multifamily Buildings Served} by WAP in PY 2008

\begin{tabular}{lccc} 
Measure & $\begin{array}{c}\text { Rate for Single } \\
\text { Family }\end{array}$ & $\begin{array}{c}\text { Rate for Large } \\
\text { Multifamily }\end{array}$ & $\begin{array}{c}\text { Highest Expected } \\
\text { Energy Impact }\end{array}$ \\
\hline Bypass Air Sealing & $79 \%$ & $66 \%$ & w/Blower Door=20\% \\
Attic Insulation & $70 \%$ & $56 \%$ & None Existing=31\% \\
Wall Insulation & $29 \%$ & $8 \%$ & Dense Pack=6\% \\
Other Insulation & $36 \%$ & $10 \%$ & Floor Insulation $=5 \%$ \\
Furnace Replacement & $22 \%$ & $36 \%$ & ECM $* 33 \%$ \\
Water Heater Replacement & $9 \%$ & $22 \%$ & ECM $=20 \%$ \\
Refrigerator & $12 \%$ & $42 \%$ & ECM $=44 \%$ \\
\hline * Energy Conservation Measure & & &
\end{tabular}

\section{Energy Savings for the National Non- New York City Sample}

Outside the New York City (NYC) area, the evaluation for PY 2008 found that most of the large multifamily buildings for which data could be retrieved were those with unit-level heating and water heating systems. In addition, the final analysis sample was relatively small and does not appear to be representative of the overall population of large multifamily buildings. Tables 5-7 present energy savings information for these buildings because they furnish information about what energy was saved in some large multifamily buildings. However, these findings cannot be projected to the overall population of large multifamily buildings treated by the WAP program in PY 2008.

Table 5 shows that the gross gas savings for gas heated buildings in PY 2008 was 81 therms ${ }^{1}$ per unit per year. During the same period, the comparison group of buildings (PY 2009 clients) reduced their usage by 5 therms per unit without receiving any treatments, so net savings due to the program for the buildings with sufficient data for analysis was 76 therms $(8.4 \%)$.

\footnotetext{
${ }^{1}$ 100,000 British Thermal Units
} 
Table 5. PY 2008 WAP Energy Impacts for Large Multifamily Buildings - Non-NYC Gross and Net Gas Savings (therms/unit/year) for Natural Gas Main Heat

\begin{tabular}{lcccccc} 
Group/Breakout & $\begin{array}{c}\text { \# of } \\
\text { Accounts }\end{array}$ & $\begin{array}{c}\text { Gas Use } \\
\text { Pre-WAP }\end{array}$ & $\begin{array}{c}\text { Gas Use } \\
\text { Post-WAP }\end{array}$ & $\begin{array}{c}\text { Gross } \\
\text { Savings }\end{array}$ & $\begin{array}{c}\text { Net } \\
\text { Savings }\end{array}$ & \% of Pre \\
\hline Treatment & 94 & 903 & 822 & 81 & $76( \pm 36)$ & $8.4 \%( \pm 3.9 \%)$ \\
Comparison & 44 & 739 & 734 & 5 & & \\
\hline
\end{tabular}

Weatherization of gas heated apartments in large multifamily also can result in savings of electricity. For example, air sealing and insulation can reduce the demand for air conditioning in the summer. In addition, many WAP units also have base load measures such as refrigerators and energy efficient lights installed. Table 6 shows that the gross electric savings for gas heated buildings with sufficient data for analysis was $200 \mathrm{kWh}$ per unit and the net savings was estimated to be $275 \mathrm{kWh}(7.4 \%)$.

Table 6. PY 2008 WAP Energy Impacts for Large Multifamily Buildings - Non-NYC Gross and Net Electric Savings (kWh/unit/year) for Natural Gas Main Heat

\begin{tabular}{lcccccc} 
Usage Component & $\begin{array}{c}\# \\
\text { Accounts }\end{array}$ & $\begin{array}{c}\text { Elec Use } \\
\text { Pre-WAP }\end{array}$ & $\begin{array}{c}\text { Elec Use } \\
\text { Post-WAP }\end{array}$ & $\begin{array}{c}\text { Gross } \\
\text { Savings }\end{array}$ & Net Savings & \% of Pre \\
\hline Treatment Group & 118 & 3,709 & 3,504 & 205 & & \\
Comparison & 36 & 5,868 & 5,938 & -70 & $275( \pm 378)$ & $7.4 \%( \pm 10.2 \%)$ \\
\hline
\end{tabular}

Table 7 shows that the gross electric savings per unit for electric heated buildings in PY 2008 was 4,951 $\mathrm{kWh}$ per year. Since there were very few comparison accounts, no net savings analysis was conducted.

Table 7. PY 2008 WAP Energy Impacts for Large Multifamily Buildings - Non-NYC Gross and Net Electric Savings (kWh/unit/year) for Electric Main Heat

\begin{tabular}{lcccccc} 
Group/Breakout & $\begin{array}{c}\text { \# of } \\
\text { Accounts }\end{array}$ & $\begin{array}{c}\text { Use Pre- } \\
\text { WAP }\end{array}$ & $\begin{array}{c}\text { Use Post- } \\
\text { WAP }\end{array}$ & $\begin{array}{c}\text { Gross } \\
\text { Savings }\end{array}$ & $\begin{array}{c}\text { Net } \\
\text { Savings }\end{array}$ & \% of Pre \\
\hline Treatment & 68 & 15,401 & 10,450 & 4,951 & n/a & $32.1 \%( \pm 7.8 \%)$ \\
\hline
\end{tabular}

The findings presented in Tables 5 through 7 furnish information on the amount of energy saved in the buildings for which the energy savings analysis could be completed. However, since these buildings are not representative of the overall population of buildings outside the NYC area that were served, the data cannot be used to project energy savings or cost-effectiveness for the program.

\section{Energy Savings for the NYC Sample}

In the NYC area, the evaluation found that most of the large multifamily buildings treated by the program had central heating and water heating systems. By working directly with each local agency, the evaluation was able to collect both the master-meter account numbers for the building and unit-level account numbers for apartments. In addition, the evaluation was able to identify fuel oil companies that supplied fuel oil to the buildings and retrieve usage information for many of those buildings. Tables 8-10 present energy savings information for the buildings weatherized by the NYC area agencies. This analysis allows us to develop projectable estimates of the gross energy savings for the WAP program in NYC area large multifamily buildings for PY 2008. 
Table 8 shows the gross natural gas and fuel oil usage impacts for the sample of large multifamily buildings weatherized in the NYC area in PY 2007-2009. The gross gas savings are 82 therms per year per unit (12.5\%). The gross fuel oil savings are estimated to be 234 therms per year per unit $(24.0 \%)$. The high level of savings for fuel oil buildings can be attributed to higher pre-weatherization usage per unit and a higher rate of heating equipment replacement.

Table 8. PY 2007-2009 WAP Energy Impacts for Large Multifamily Buildings - NYC Gross Fuel Savings (therms/unit/year)

\begin{tabular}{lcccccc} 
Group/Breakout & $\begin{array}{c}\text { \# of } \\
\text { Accounts }\end{array}$ & $\begin{array}{c}\text { Gas Use } \\
\text { Pre-WAP }\end{array}$ & $\begin{array}{c}\text { Gas Use } \\
\text { Post-WAP }\end{array}$ & $\begin{array}{c}\text { Gross } \\
\text { Savings }\end{array}$ & $\begin{array}{c}\text { Net } \\
\text { Savings }\end{array}$ & \% of Pre \\
\hline Natural Gas & 65 & 656 & 574 & 82 & $\mathrm{n} / \mathrm{a}$ & $12.5 \%( \pm 4.2 \%)$ \\
Fuel Oil & 41 & 973 & 739 & 234 & $\mathrm{n} / \mathrm{a}$ & $24.0 \%( \pm 7.2 \%)$ \\
\hline
\end{tabular}

In the NYC WAP program, weatherization services can affect electric usage in three ways. First, lighting measures and occupancy sensors in common areas can reduce building-level electric usage. Second, weatherization of the building can result in unit-level reductions in air conditioning demand. Finally, installation of base load measures such as refrigerators and lights also can reduce unit-level electric usage. Table 9 shows that the gross electric savings for NYC buildings was $172 \mathrm{kWh}$ per unit $(6.7 \%)$ for the common area and $816 \mathrm{kWh}$ per unit $(23.2 \%)$ for individual units. The major factor in this result was that almost 50 percent of apartments in NYC buildings had refrigerator replacements.

Table 9. PY 2007-2009 WAP Energy Impacts for Large Multifamily Buildings - NYC Gross Electric Savings (kWh/unit/year)

\begin{tabular}{lcccccc} 
Usage Component & $\begin{array}{c}\# \\
\text { Accounts }\end{array}$ & $\begin{array}{c}\text { Elec Use } \\
\text { Pre-WAP }\end{array}$ & $\begin{array}{c}\text { Elec Use } \\
\text { Post-WAP }\end{array}$ & $\begin{array}{c}\text { Gross } \\
\text { Savings }\end{array}$ & Net Savings & \% of Pre \\
\hline Common Area & 147 & 2,557 & 2,385 & 172 & $\mathrm{n} / \mathrm{a}$ & $6.7 \%$ \\
Unit Level & 251 & 3,513 & 2,697 & 816 & $\mathrm{n} / \mathrm{a}$ & $23.2 \%$ \\
\hline
\end{tabular}

\section{Projected Energy Savings}

One goal of the evaluation is to project total energy savings and energy savings per unit for the PY 2008 WAP program. While the measured savings statistics furnish valuable information, they do not furnish direct estimates for the entire population of housing units treated by WAP. A series of analysis procedures was used to develop savings estimates for the population of housing units served by the program.

As discussed above, the data furnished by the weatherization agencies and utilities for large multifamily buildings outside New York City were not sufficient to develop estimates of energy savings for the population of buildings served by the WAP program. While energy savings estimates could be developed for some buildings, those buildings were not representative of the overall population of large multifamily buildings weatherized outside New York City. ${ }^{2}$

\footnotetext{
${ }^{2}$ Some WAP grantees required agencies to collect master-meter account numbers and unit-level account numbers for large multifamily buildings weatherized by the program, but others did not. As a result, the data collected for the PY 2008 evaluation did not cover certain geographic areas and therefore was not representative of the buildings treated by the program in PY 2008.
} 
Since about one-third of all large multifamily units weatherized by the WAP program in PY 2008 were in the New York City area, the evaluation team implemented a special set of procedures for collecting data from NYC agencies and utilities. Those procedures resulted in estimates of energy savings for NYC large multifamily buildings. Table 10 summarizes the estimates of projected energy savings per unit for NYC large multifamily buildings for PY 2008.

Table 10. PY 2008 WAP Energy Impacts for Large Multifamily Buildings - NYC Gross Savings by Main Heating Fuel

\begin{tabular}{lccc}
\hline Main Heating Fuel & $\begin{array}{c}\text { Number of } \\
\text { Units }\end{array}$ & $\begin{array}{c}\text { Heating Fuel Savings } \\
\text { (MMBtu*/unit/year) }\end{array}$ & $\begin{array}{c}\text { Electric Savings } \\
\text { (kWh/unit/year) }\end{array}$ \\
\hline Natural Gas & 3,425 & 12.4 & 943 \\
Fuel Oil & 1,919 & 23.5 & 881 \\
\hline All Fuels & 5,344 & 16.4 & 921 \\
\hline
\end{tabular}

* Mean Million British Thermal Units

\section{Program Energy Cost Savings and Cost-Effectiveness}

The evaluation estimated the cost savings and cost-effectiveness in the following way.

- Energy Savings - The time series of energy savings was estimated for each sampled housing unit based on first year savings and the estimated life of the measure.

- Cost Savings - Current and projected energy prices were used to transform the energy savings time series to a cost savings time series for each sampled housing unit.

- Service Delivery Costs - Subgrantees furnished information on the service delivery cost for each sampled housing unit.

- Cost Effectiveness - Program cost-effectiveness was estimated by comparing the net present value of energy savings to the service delivery costs for energy measures.

The analysis in this report is restricted to a comparison of the energy benefits to the service delivery costs for energy measures and incidental home repairs. The overarching impact report will compare energy and nonenergy benefits to total program costs.

Since the evaluation was not able to develop projectable estimates of energy savings for the population of large multifamily buildings outside New York City, it was not possible to develop cost savings or costeffectiveness information for that population of weatherized units. However, the evaluation was able to develop estimates for the buildings weatherized by New York City-area agencies.

Tables 11 and 12 furnish estimates of the energy cost-effectiveness of the program for large multifamily buildings using two different analysis frameworks. The first scenario (Table 11) compares the net present value lifetime energy cost savings to the WAP-funded energy efficiency measure costs to calculate the savings-to-investment ratio (SIR) by main heating fuel. The second scenario (Table 12) compares cost savings to the cost of energy efficiency measures paid for by all sources. The WAP program is highly leveraged in the New York City multifamily market; building owners are required to make a significant contribution to the total cost of program measures. Table 11, then, shows the cost-effectiveness with respect to the funds provided by WAP while Table 12 shows the cost-effectiveness of all funds spent on the building. 
Table 11 shows that the SIR is estimated to be 2.77 for the population of large multifamily buildings in New York City when only WAP program expenditures are included in the program costs. It is greater than 1.0 for all main heating fuel types, but the SIR for fuel oil main heat is more than three times the rate for buildings with natural gas main heat; the SIR for buildings with natural gas main heat was 1.27 and the SIR for buildings with fuel oil main heat was 4.64.

Table 11. PY 2008 WAP Impacts for Large Multifamily Buildings - NYC

Energy Cost Savings, Efficiency Measure Costs, and Cost-Effectiveness by Main Heating Fuel WAP Program Expenditures Only

\begin{tabular}{lcc|c|ccc} 
& \multicolumn{2}{c}{$\begin{array}{c}\text { Energy Cost Savings per Unit } \\
\text { (present value of lifetime savings) }\end{array}$} & \multicolumn{2}{c}{ Costs per Unit \& Cost Effectiveness } \\
\cline { 2 - 7 } & $\begin{array}{c}\text { Fuel } \\
\text { Savings } \\
\text { per Unit }\end{array}$ & $\begin{array}{c}\text { Electric } \\
\text { Savings } \\
\text { per Unit }\end{array}$ & $\begin{array}{c}\text { Total } \\
\text { Savings per } \\
\text { Unit }\end{array}$ & $\begin{array}{c}\text { Measure } \\
\text { Costs per Unit }\end{array}$ & $\begin{array}{c}\text { Net Benefits } \\
\text { per Unit }\end{array}$ & $\begin{array}{c}\text { Savings/ } \\
\text { Investment } \\
\text { Ratio }\end{array}$ \\
\hline Natural Gas & $\$ 1,203$ & $\$ 1,207$ & $\$ 2,410$ & $\$ 1,899$ & $\$ 511$ & 1.27 \\
Fuel Oil & $\$ 10,296$ & $\$ 1,241$ & $\$ 11,538$ & $\$ 2,485$ & $\$ 9,053$ & 4.64 \\
\hline All Buildings & $\mathbf{\$ 5 , 2 3 7}$ & $\mathbf{\$ 1 , 2 2 2}$ & $\mathbf{\$ 6 , 4 6 0}$ & $\mathbf{\$ 2 , 1 7 9}$ & $\mathbf{\$ 4 , 2 8 1}$ & $\mathbf{2 . 7 7}$ \\
\hline
\end{tabular}

Table 12 shows that the SIR is estimated to be 1.82 for the population of large multifamily buildings in New York City when all sources of funding are included in the program costs. The SIR for buildings with natural gas main heat was 0.80 and the SIR for buildings with fuel oil main heat was 3.10.

Table 12. PY 2008 WAP Impacts for Large Multifamily Buildings - NYC

Energy Cost Savings, Efficiency Measure Costs, and Cost-Effectiveness by Main Heating Fuel Program Expenditures - All Funding Sources

Energy Cost Savings per Unit (present value of lifetime savings)

Costs per Unit \& Cost Effectiveness

\begin{tabular}{lcc|c|ccc}
\cline { 2 - 6 } Heating Fuel & $\begin{array}{c}\text { Fuel } \\
\text { Savings } \\
\text { per Unit }\end{array}$ & $\begin{array}{c}\text { Electric } \\
\text { Savings } \\
\text { per Unit }\end{array}$ & $\begin{array}{c}\text { Total } \\
\text { Savings per } \\
\text { Unit }\end{array}$ & $\begin{array}{c}\text { Measure } \\
\text { Costs per Unit }\end{array}$ & $\begin{array}{c}\text { Net Benefits } \\
\text { per Unit }\end{array}$ & $\begin{array}{c}\text { Savings/ } \\
\text { Investment } \\
\text { Ratio }\end{array}$ \\
\hline Natural Gas & $\$ 1,203$ & $\$ 1,207$ & $\$ 2,410$ & $\$ 3,029$ & $-\$ 619$ & 0.80 \\
Fuel Oil & $\$ 10,296$ & $\$ 1,241$ & $\$ 11,538$ & $\$ 3,721$ & $\$ 7,817$ & 3.10 \\
\hline All Buildings & $\mathbf{\$ 5 , 2 3 7}$ & $\mathbf{\$ 1 , 2 2 2}$ & $\mathbf{\$ 6 , 4 6 0}$ & $\mathbf{\$ 3 , 3 3 6}$ & $\mathbf{\$ 3 , 1 2 8}$ & $\mathbf{1 . 8 2}$ \\
\hline
\end{tabular}

Comparing the measure costs in Table 11 to those costs in Table 12 furnishes information on the average investment by owners of large multifamily buildings. For natural gas, the WAP investment was $\$ 1,899$ per unit (Table 11) and the total investment was $\$ 3,029$ (Table 12); WAP paid for 63 percent of the measure costs for those buildings. For fuel oil, the WAP investment was $\$ 2,485$ per unit (Table 11) and the total investment was $\$ 3,721$ (Table 12); WAP paid for 67 percent of the measure costs for those buildings.

The overall SIR for large multifamily buildings including all funding sources was 1.82 . This result is heavily influenced by the high level of energy savings and the high average cost of the fuel oil heated buildings in the New York City sample of buildings. 


\section{INTRODUCTION}

The purpose of this report is to disseminate the findings from an analysis of the energy savings, cost savings, and cost-effectiveness for large multifamily buildings (i.e., buildings with 5 or more housing units) treated by U.S. Department of Energy's (DOE) Weatherization Assistance Program (WAP) during Program Years (PY) 2007, 2008, and 2009. The main focus of this study is on PY 2008. The analysis uses data from a number of sources to characterize the population of large multifamily buildings that were served by the program, estimate the gross and net change in energy usage for treated buildings, make projections for the first year and longer-term cost savings associated with the energy savings, and assess the cost-effectiveness of the program in terms of direct energy benefits.

This is one of a number of energy impact reports developed for the National WAP Evaluation. The full set of energy impact reports includes:

- $\quad$ Energy Impacts for Mobile Homes

- Energy Impacts for Single Family Homes

- Energy Impacts for Small Multifamily Buildings

- Energy Impacts for Large Multifamily Buildings

- Energy and Nonenergy Impacts of the Weatherization Assistance Program

To the extent possible, the WAP program applies consistent procedures across all clients. However, there are substantial differences in energy equipment, building configuration, and retrofit opportunities across building types. By furnishing reports for each building type, the evaluation is able to give policymakers an understanding of the specific challenges associated with maximizing energy impacts from each building type. The summary report then furnishes comprehensive information on the program's energy and nonenergy impacts.

\subsection{NATIONAL WEATHERIZATION ASSISTANCE PROGRAM EVALUATION OVERVIEW}

WAP was created by Congress in 1976 under Title IV of the Energy Conservation and Production Act. The purpose and scope of the Program as currently stated in the Code of Federal Regulations (CFR) 10 CFR 440.1 is "to increase the energy efficiency of dwellings owned or occupied by low-income persons, reduce their total residential energy expenditures, and improve their health and safety, especially lowincome persons who are particularly vulnerable such as the elderly, persons with disabilities, families with children, high residential energy users, and households with high energy burden." (Code of Federal Regulations, 2011)

At the request of DOE, Oak Ridge National Laboratory (ORNL) developed a comprehensive plan for a national evaluation of WAP that was published in 2007. DOE furnished funding to ORNL in 2009 for a national evaluation for Program Years 2007 and 2008, with a particular emphasis on PY 2008. ORNL subcontracted evaluation research to APPRISE Incorporated and its partners (the Energy Center of Wisconsin, Michael Blasnik and Associates, and Dalhoff Associates LLC). The Scope of Work (SOW) for the evaluation includes the following components: 
- Impact Assessment - Characterization of the weatherization network and the households that are income-eligible for WAP, measurement and monetization of the energy and nonenergy impacts of the program, and assessment of the factors associated with higher levels of energy savings, cost savings, and cost-effectiveness.

- Process Assessment - Direct observation of how the weatherization network delivers services and assessment of how service delivery compares to national standards and documentation of how weatherization staff and clients perceive service delivery.

- Special Technical Studies - Examination of the performance of the program with respect to technical issues such as air sealing, duct sealing, furnace efficiency, and refrigerators.

- Synthesis Study - Synthesis of the findings from this evaluation into a comprehensive assessment of the success of the program in meeting its goals and identification of key areas for program enhancement.

This analysis of large multifamily building energy impacts is part of the Impact Assessment.

\subsection{LARGE MULTIFAMILY BUILDING STUDY OVERVIEW}

This report furnishes information on how housing units in large multifamily buildings were served by the WAP program in PY 2008. This analysis is complex because weatherization of a multifamily building can vary on several dimensions:

- Energy Equipment - Some buildings have centralized energy equipment (e.g., one heating system for all units in the building) while others have energy equipment for each unit (e.g., electric baseboard heat for each unit).

- Air Sealing and Insulation - In some buildings, the program can seal and insulate individual housing units (i.e., apartments) while in others the entire building must be treated as an integrated system for air sealing and insulation.

- Common Areas - In some buildings, there are significant common areas including lobbies, stairways, and, hallways. In other buildings, each housing unit has direct access to the outside and there are no common areas.

As a result, program resources are sometimes focused on building-level measures; at other times, they are restricted to unit-level measures, and often include both types of measures. This report documents the number of housing units in large multifamily buildings that were served by the program, furnishes statistics on the weatherization measures installed at the unit and building levels, estimates unit-level and building-level energy savings, and assesses the cost-effectiveness of installed measures.

\subsubsection{National Sample of Weatherized Housing Units}

At the national level, the evaluation team collected information on all types of weatherized housing units from a representative sample of subgrantees (i.e., local weatherization agencies). Data for the national sample of multifamily buildings analyzed in this report were collected as part of that process. The data collection and analysis included:

- Building and Housing Unit Sample - The evaluation team worked with grantees and subgrantees to select a representative sample of weatherized buildings served by the program in PYs 2007, 
2008, and 2009. When a sampled building was determined to be a large multifamily building, the data collection process included development of a list of qualified housing units in each building.

- Diagnostics and Measures - Subgrantees supplied information on diagnostic tests conducted, installed measures, and measures costs for a sample of buildings and units that were treated by the WAP program.

- Energy Data Collection - The evaluation team collected information from energy suppliers to assess the amount of energy used at the building-level and unit-level before and after the installation of weatherization measures.

- Energy Data Analysis - Statistical procedures were used to develop normalized estimates of the difference in usage between the pre- and post-weatherization periods for the building for which data were available. However, because of the small sample sizes, it was not possible to develop robust estimates of the net energy impacts associated with service delivery for the entire population of large multifamily buildings served by the program.

This combined set of procedures was effective in characterizing the population of large multifamily buildings served by the program. However, the data were not sufficient to furnish estimates of the energy savings and cost-effectiveness of the program for large multifamily buildings.

\subsubsection{New York City Large Multifamily Building Study}

The evaluation team conducted a special study of large multifamily buildings weatherized by New York City agencies. These agencies weatherized about 33 percent of all the units in large multifamily buildings that were weatherized in 2008. The data collection and analysis for this study included:

- Building Identification - We used the New York State WAP program database to identify the large multifamily buildings with 5 or more units that were weatherized by New York City agencies in 2007, 2008, and 2009.

- Building-Level Data Collection - Evaluation team staff visited each agency and retrieved detailed information on pre-weatherization energy usage, recommended measures, installed measures, and installation costs.

- Energy Data Collection - The evaluation team collected information from energy suppliers (natural gas, electricity, and fuel oil) to assess the amount of energy used at the building level and unit level before and after the installation of weatherization measures.

These procedures allowed the evaluation team to develop estimates of building-level and unit-level savings of natural gas, fuel oil, and electricity, and to examine the cost-effectiveness of the program. While these buildings are not representative of the entire population of large multifamily buildings served by the program, they do represent a substantial proportion of the population.

\subsubsection{Climate Zone Analysis Framework}

Figure 1.1 shows how states were assigned to Climates Zones for purposes of this study. 


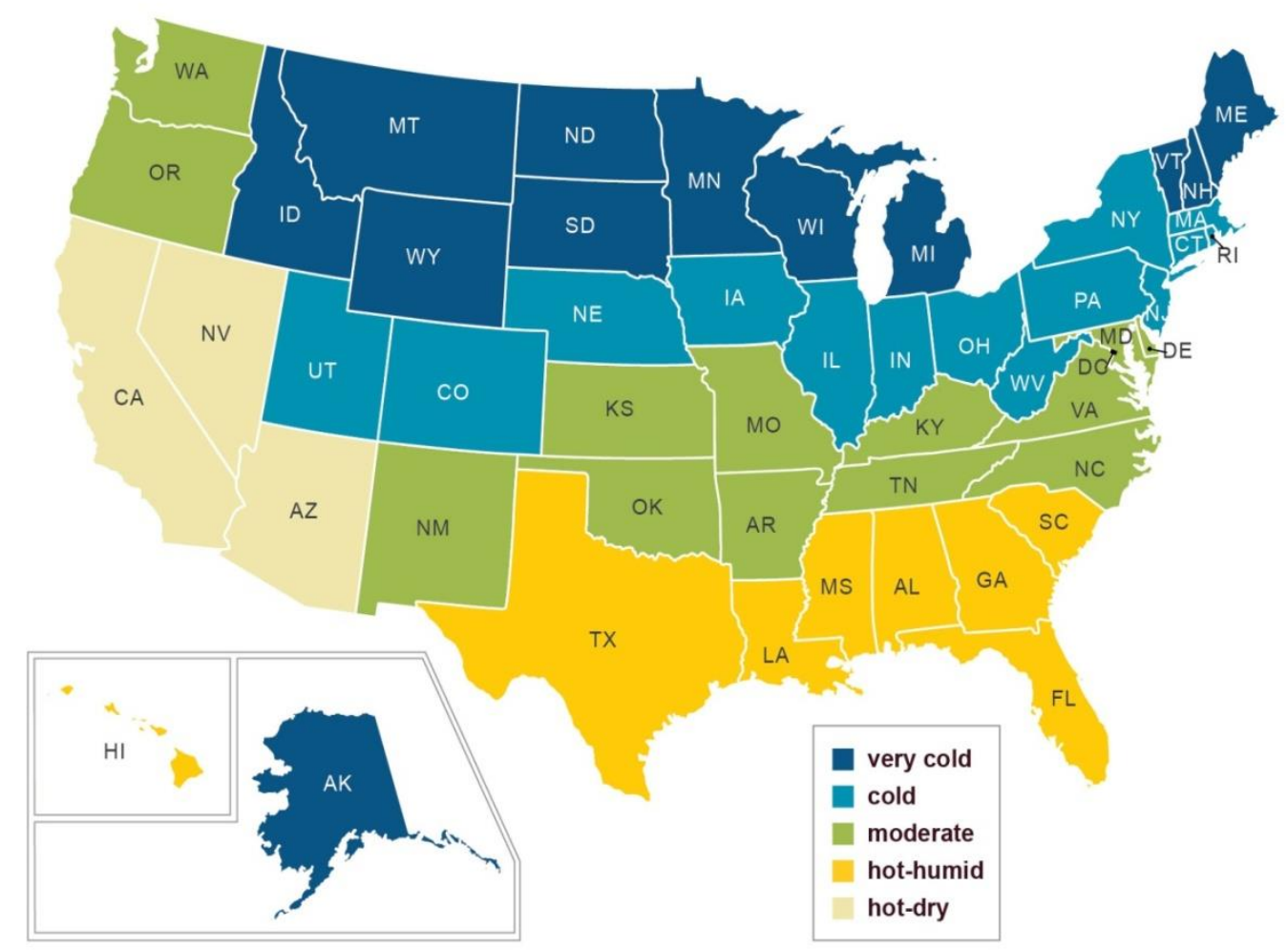

Figure 1.1. Climate Zone Map for the PY 2008 Evaluation

\subsection{ORGANIZATION OF THE LARGE MULTIFAMILY IMPACT REPORT}

The report consists of five sections, including:

- Section 1 - Introduction: Furnishes an overview of the Weatherization Assistance Program Evaluation, the WAP Impact Evaluation, and the evaluation of multifamily buildings.

- Section 2 - Overview of Data Collection Methodology: Documents the data sources that were used to prepare this report.

- Section 3 -Production, Building Characteristics, and Installed Measures: Furnishes information on the number and distribution of units in large multifamily buildings, building characteristics, pre-weatherization conditions, installed measures, and post-weatherization conditions for large multifamily buildings served by the WAP program.

- Section 4 - Energy Usage Impacts - Furnishes estimates of the energy savings and the determinants of energy savings for large multifamily buildings served by the program, with a special focus on the findings from the New York City large multifamily building study.

- Section 5 - Cost Savings, Measure Costs, and Cost-Effectiveness - Furnishes estimates of the cost savings and cost-effectiveness for large multifamily buildings served by the program, with a special focus on the findings from the New York City large multifamily building study.

This report is designed to complement other Energy Impact Reports and contribute to the Summary Report on Energy and Nonenergy Impacts of the WAP program. 


\section{OVERVIEW OF DATA COLLECTION METHODOLOGY}

The purpose of the large multifamily building energy impact study is to measure the energy savings, cost savings, and cost effectiveness for large multifamily buildings treated by WAP during Program Years 2007, 2008, and 2009. The main focus of the study is on PY 2008. The study used data from a number of sources, including:

- Grantees (i.e., States)

- Subgrantees (i.e., Local Agencies)

- Electric and Gas Utilities

- Delivered Fuel Submeter Studies

- U.S. Energy Information Administration (EIA) Energy Price Data and Projections

- U.S. National Climatic Data Center (NCDC) Weather Data

This section of the report documents the data collection procedures and outcomes for the two sources of data used for this study, a representative national sample of weatherized units in all buildings and a census of large multifamily buildings weatherized in New York City. Together these data sources furnish information that is used to characterize large multifamily building weatherization in the WAP program.

\subsection{SUBGRANTEE AND BUILDING/CLIENT SAMPLE - NATIONAL SAMPLE}

The first step in the data collection process was to select a representative national sample of buildings and clients served in PY 2007, 2008, and 2009. The evaluation used a two-stage sampling procedure. In the first stage, a sample of subgrantees was selected. In the second stage, a sample of buildings and clients was selected from sampled subgrantees.

\subsubsection{Subgrantee Sampling Procedures}

The ORNL Evaluation Team selected a sample of 400 agencies with probability proportionate to size. The measure of size was planned program funding for PY 2008. The sampling procedure involved the following steps:

- Grantee Allocation - Each grantee was allocated a share of the sample of 400 subgrantees based on its share of PY 2008 program funding.

- Subgrantee Sample - For each grantee, a set of subgrantees was sampled with probability proportionate to size based on PY 2008 planned program funding.

The outcome of this procedure was that states with higher WAP funding had more sampled subgrantees and the larger subgrantees had a higher probability of selection. These procedures furnished a representative and statistically efficient sample of clients.

\subsubsection{Building/Client Sampling Procedures}

The APPRISE Evaluation Team contacted each of the sampled agencies to get information on the buildings and clients served in PYs 2007, 2008, and 2009. The sampling procedures involved the following steps:

- Building/Client List - Each subgrantee furnished a list of buildings weatherized for PYs 2007, 2008, and 2009. 
- Building/Client Sample - Subgrantees' lists were stratified into two groups, utility main heat (i.e., electric or natural gas) and delivered fuel main heat (i.e., fuel oil, propane, wood, or coal).

Sampling procedures selected one-third of the buildings in the utility main heat stratum and onefourth of the buildings in the delivered fuel main heat stratum; for each subgrantee a minimum of 7 buildings was selected for each fuel group for each year.

- Client Information - As part of the data collection process, information was collected for each eligible client in a weatherized building. For single family site built homes and mobile homes, there was only one client listed per building. However, for multifamily buildings, there often was more than one eligible client listed for the building.

\subsubsection{Subgrantee and Client Sampling Statistics and Response Rates}

The ORNL Evaluation Team selected a census of 51 grantees and a sample of 400 subgrantees. The following statistics describe the sample and the response rates.

- Grantees

○ Population - 51 grantees received WAP funding in PY 2008

- Census - All 51 grantees were included in the sample

○ Response - All 51 grantees responded to information requests (100\%)

- Subgrantees

○ Population

- 905 subgrantees were listed in grantee plans for PY 2008

- 879 subgrantees actually received WAP funding in PY 2008

○ Sample

- 400 of 905 subgrantees were sampled

- 395 of 879 funded subgrantees were sampled

- $\quad$ Response - 379 of 395 funded subgrantees furnished a list of buildings (96\%).

Not all subgrantees reported that they weatherized large multifamily buildings. Of the 379 funded subgrantees that furnished a list of buildings and clients, 116 subgrantees in 30 states reported that they weatherized large multifamily buildings in PY 2008.

For the national sample, the Evaluation Team selected a sample of 22,134 PY 2008 clients from the 379 funded subgrantees that furnished a list of clients. That sample included 302 large multifamily buildings with 5,410 clients.

\subsection{SUBGRANTEE DATA COLLECTION - NATIONAL SAMPLE}

Subgrantees were asked to furnish two kinds of client data to support the evaluation, utility account information and service delivery data.

\subsubsection{Utility Account Information}

Subgrantees were asked to furnish main heating fuel, utility account numbers, and copies of data release waivers for sampled buildings and clients that heated with either natural gas or electricity. For multifamily buildings, this was more complex than for other building types because several different kinds of accounts may need to be collected to accurately track all of the energy used in the building. Some 
multifamily buildings have master meter accounts for all building uses, others have master meter accounts for centralized heating and common areas and electric accounts for each unit, and for some buildings all energy accounts are at the unit level. The utility account data collection needed to be tailored to the account configuration in each building.

The following statistics describe the response rate to the overall utility account data request:

- Sample - 395 funded subgrantees were asked to furnish a list of clients

- Client List Response - 379 of 395 funded subgrantees furnished a list of clients (96\%)

- Utility Data Response - 368 of 395 funded subgrantees furnished utility account information for sampled clients (93\%)

The following statistics describe the response rate for large multifamily buildings:

- Sample - The Evaluation Team selected a sample of 282 PY 2008 large multifamily buildings with natural gas or electric main heat from the 116 funded subgrantees that reported weatherizing large multifamily buildings and furnished client lists.

- Responding Subgrantees - Of the 116 subgrantees that reported weatherizing large multifamily buildings, 99 responded to the utility data request. These grantees had 228 of the 282 large multifamily buildings in the sample $(81 \%)$.

- Main Heating Supplier - The 99 subgrantees that responded furnished the heating energy supplier information for 194 of their 228 large multifamily buildings (85\%).

- Electric Data Supplier - The 99 subgrantees that responded furnished electric supplier information for 203 of their 228 large multifamily buildings at either the building level or the housing unit level (89\%)

Some subgrantees collected supplier information only for the main heating fuel and did not collect information for the client's electric company if it was not the main heating fuel. Some subgrantees collected common area electric account information. Some subgrantees collected unit-level account information.

\subsubsection{Client Service Delivery Data}

Subgrantees were asked to furnish service delivery information for all PY 2008 sampled buildings. The requested service delivery data included:

- Housing unit characteristics

- Pre-weatherization conditions

- Installed measures and costs

- Post-weatherization conditions

The following statistics describe the response rate to this data request for large multifamily buildings:

- Building Lists - 116 funded subgrantees reported that they weatherized large multifamily buildings. 
- Service Delivery Data Response - 99 of the 116 subgrantees that weatherized large multifamily buildings furnished service delivery data $(85 \%)$.

The following statistics describe the response rate in terms of buildings:

- Sample - The Evaluation Team selected a sample of 302 PY 2008 large multifamily buildings from the subgrantees that weatherized this type of building.

- $\quad$ Building Data - The subgrantees that responded furnished service delivery data for 282 of the 302 large multifamily buildings (93\%).

- Housing Units - The buildings for which data were submitted included 4,533 of the 5,410 housing units in sampled large multifamily buildings (84\%).

Overall, the agencies furnished service delivery data for a large share of the large multifamily buildings and the housing units in large multifamily buildings.

\subsection{NATURAL GAS AND ELECTRIC USAGE DATA COLLECTION - NATIONAL SAMPLE}

For all sampled clients that heated with either natural gas or electricity, the evaluation team requested data from the company that supplied the client's main heating fuel - natural gas or electricity. The supplier was asked to furnish monthly data for the period 1/1/2006 through 12/31/2010.

The following statistics describe the response rates for large multifamily buildings:

- Natural Gas or Electric Main Heating Fuel

- Companies - 54 natural gas and electric companies were identified for one or more sampled PY 2008 large multifamily buildings.

○ Company Response - 43 of the 54 companies furnished data for one or more of the sampled buildings (80\%).

○ Building Response - Data were received for 213 of the 302 sampled PY 2008 large multifamily buildings (71\%).

- Electric Usage for Natural Gas Main Heat Clients

- Companies - 44 electric companies were identified as the electric supplier for one or more PY 2008 large multifamily buildings that heat with natural gas.

- Company Response - 31 of the 41 electric companies furnished data for one or more of the sampled buildings (76\%).

- Building Response - Data were received for 130 of the 302 sampled PY 2008 large multifamily buildings (43\%).

- Housing Unit Response - Unit-level electric data were received for 1,029 of the 5,410 units in those buildings (19\%). 
These statistics furnish information on clients for whom any data were furnished. Not all usage records were adequate for all parts of the billing analysis procedures.

\subsection{NEW YORK CITY LARGE MULTIFAMILY STUDY}

Nationally, about 25 percent of low-income households live in large multifamily buildings. ${ }^{3}$ In New York City, the incidence of low-income households in large multifamily buildings is 67 percent, almost three times the national rate. ${ }^{4}$ In addition, many of the large multifamily buildings in New York City are highrise apartment buildings with central heating systems and common area electric usage. For that reason, the New York City weatherization agencies have developed special procedures for delivering weatherization services to these buildings. To better understand how these services are delivered and the energy impacts that are achieved, the Evaluation Plan specified that the Evaluation Team conduct a special study of New York City large multifamily buildings. ${ }^{5}$

The study targeted buildings with 5 or more units that had central heating and water heating systems. The study data collection procedures included the following:

- Population - The Evaluation Team developed a list of all multifamily buildings with 5 or more units that were weatherized by the 16 New York City area weatherization subgrantees during PY 2007, 2008, and 2009. In total, 243 buildings with 13,467 units qualified for the study. For PY 2008, those buildings represented over 90 percent of all housing units weatherized by these 16 subgrantees.

- $\quad$ Building Data - Evaluation Team staff visited each agency and collected information for the 243 targeted buildings. They found that 235 of the 243 buildings met the criteria for inclusion in the study (i.e., had central heating and water heating systems). They were able to collect information for 223 of the 235 buildings (95\%). Those buildings had 83 percent of the housing units that were in buildings that we qualified for the study.

- Energy Usage Data - The Evaluation Team attempted to collect building-level heating fuel information (both natural gas and fuel oil), common area electric data, and unit-level electric data for all eligible buildings. The response rates by fuel type were:

- Fuel Oil Data - Fuel oil companies furnished data for 50 of the 101 buildings that used fuel oil as a main heating fuel $(50 \%)$.

- Natural Gas Data - Gas companies furnished data for 72 of the 90 buildings that used natural gas as a main heating fuel $(80 \%)$.

- Common Area Electric Data - Electric companies furnished common area electric data for 152 of the 223 buildings (69\%).

\footnotetext{
${ }^{3}$ Source: Tabulation from 2010 American Community Survey (ACS).

${ }^{4}$ Source: Tabulation from the 2008-2010 American Community Survey (ACS).

${ }^{5}$ For the ARRA Period study of large multifamily buildings, special data collection procedures were implemented in New York, Illinois, Wisconsin, and Ohio. In New York, 88 percent of the buildings treated by the program had building-level heating equipment for the building. In others states, the majority of buildings had unit-level heating equipment. In Illinois, 70 percent of the buildings had unit-level heating equipment. In Wisconsin, 63 percent of the buildings had unit-level heating equipment. In Ohio, 93 percent of the buildings had unit-level heating equipment.
} 
- Unit-Level Electric Data - Electric companies furnished unit-level electric data for 53 of the 223 buildings (24\%); those buildings included 629 of the 12,128 units in eligible buildings.

These special study data collection procedures furnished data for a substantial share of the targeted large multifamily buildings in New York City and also represent a significant part of the total population of large multifamily buildings weatherized by the WAP program in PY 2008. 


\section{PRODUCTION, BUILDING CHARACTERISTICS, AND INSTALLED MEASURES}

This section of the report uses detailed service delivery data furnished by the sampled subgrantees to characterize the population of housing units served by the program, including:

- Geographic Distribution of Treated Buildings

- Building Characteristics

- Pre-Weatherization Conditions

- Installed Measures

- Post-Weatherization Conditions

This report focuses on characterizing large multifamily buildings. However, since one important purpose of this analysis is to assess how weatherization of large multifamily buildings is similar to or different from weatherization of single family homes, statistics for large multifamily buildings are compared to those for single family homes.

\subsection{WAP PRODUCTION - ALL HOUSING UNIT TYPES}

The primary data source for this section of the report was data furnished by subgrantees for a sample of buildings. In total, 365 subgrantees furnished detailed information for 19,496 housing units that were served by the WAP program in PY 2008, including 4,533 housing units in 282 large multifamily buildings. Table 3.1 shows the number of sampled housing units by Climate Zone and Table 3.2 shows the number of sampled housing units by type.

Table 3.1. PY 2008 Sampled Housing Units by Climate Zone

\begin{tabular}{lcc} 
Climate Zone & PY 2008 Sampled Units & $\begin{array}{c}\text { Percent of PY 2008 } \\
\text { Sample }\end{array}$ \\
\hline Very Cold Climate & 5,340 & $27 \%$ \\
Cold Climate & 10,539 & $54 \%$ \\
Moderate Climate & 2,464 & $13 \%$ \\
Hot/Humid Climate & 623 & $3 \%$ \\
Hot/Dry Climate & 530 & $3 \%$ \\
\hline TOTAL & 19,496 & $100 \%$ \\
\hline
\end{tabular}


Table 3.2. PY 2008 Sampled Housing Units by Type

\begin{tabular}{lcc} 
Housing Unit Type & $\begin{array}{c}\text { PY 2008 Sampled } \\
\text { Units }\end{array}$ & $\begin{array}{c}\text { Percent of PY 2008 } \\
\text { Sample }\end{array}$ \\
\hline Single Family Site Built & 10,340 & $53 \%$ \\
Single Family Mobile Home & 2,826 & $15 \%$ \\
Small Multifamily (2-4 Units) & 1,798 & $9 \%$ \\
Large Multifamily (5+ Units) & 4,532 & $23 \%$ \\
\hline TOTAL & 19,496 & $100 \%$ \\
\hline
\end{tabular}

The sample of buildings supplied by WAP subgrantees was weighted to account for sampling rates and adjust for survey nonresponse. The weighting steps included the following:

- Base Weight - Each sampled building was assigned a base weight that was the inverse of the building's probability of selection.

- State-Level Adjustment - For each state, the building weights were adjusted to match state production control totals by housing unit type.

Applying the adjusted case weights furnishes estimates of the total number of housing units by Climate Zone and Housing Unit Type weatherized by WAP in PY 2008. Table 3.3 shows the weighted count of housing units by Climate Zone; 68 percent of the weatherized units were in the Very Cold and Cold Climate Zones. Table 3.4 shows the weighted count of WAP housing units by Housing Unit Type; large multifamily buildings had 18 percent of the units weatherized in PY 2008.

Table 3.3. PY 2008 Weighted Housing Units by Climate Zone

\begin{tabular}{lcc} 
Climate Zone & $\begin{array}{c}\text { PY 2008 Weighted } \\
\text { Count of Units }\end{array}$ & $\begin{array}{c}\text { Percent of PY 2008 } \\
\text { Units }\end{array}$ \\
\hline Very Cold Climate & 24,749 & $25 \%$ \\
Cold Climate & 42,233 & $43 \%$ \\
Moderate Climate & 18,794 & $19 \%$ \\
Hot/Humid Climate & 6,390 & $7 \%$ \\
Hot/Dry Climate & 5,799 & $6 \%$ \\
\hline TOTAL & 97,965 & $100 \%$ \\
\hline
\end{tabular}


Table 3.4. PY 2008 Weighted Housing Units by Type

\begin{tabular}{lcc} 
Housing Unit Type & $\begin{array}{c}\text { PY 2008 Weighted } \\
\text { Count of Units }\end{array}$ & $\begin{array}{c}\text { Percent of PY 2008 } \\
\text { Units }\end{array}$ \\
\hline Single Family Site Built & 57,518 & $59 \%$ \\
Single Family Mobile Home & 17,754 & $18 \%$ \\
Small Multifamily (2-4 Units) & 5,317 & $5 \%$ \\
Large Multifamily (5+ Units) & 17,376 & $18 \%$ \\
\hline TOTAL & 97,965 & $100 \%$ \\
\hline
\end{tabular}

The distribution of the housing unit types weatherized varies somewhat by Climate Zone. Table 3.5 shows the weighted percent of units in each Climate Zone by housing unit type. The Hot/Dry and Cold Climate Zones reported the largest percentage of units in large multifamily buildings.

Table 3.5. PY 2008 Weighted Housing Units by Climate Zone and Housing Unit Type

\begin{tabular}{lccccc} 
Climate Zone & Single Family & Mobile Home & $\begin{array}{c}\text { Small } \\
\text { Multifamily }\end{array}$ & $\begin{array}{c}\text { Large } \\
\text { Multifamily }\end{array}$ & $\begin{array}{c}\text { All Housing } \\
\text { Unit Types }\end{array}$ \\
\hline Very Cold Climate & $58 \%$ & $19 \%$ & $9 \%$ & $14 \%$ & $100 \%$ \\
Cold Climate & $57 \%$ & $14 \%$ & $6 \%$ & $24 \%$ & $100 \%$ \\
Moderate Climate & $65 \%$ & $27 \%$ & $1 \%$ & $7 \%$ & $100 \%$ \\
Hot/Humid Climate & $70 \%$ & $17 \%$ & $6 \%$ & $7 \%$ & $100 \%$ \\
Hot/Dry Climate & $43 \%$ & $19 \%$ & $1 \%$ & $36 \%$ & $100 \%$ \\
\hline TOTAL & $59 \%$ & $18 \%$ & $5 \%$ & $18 \%$ & $100 \%$ \\
\hline
\end{tabular}

\subsection{WAP PRODUCTION - LARGE MULTIFAMILY BUILDINGS}

Table 3.6 shows the distribution of housing units in large multifamily buildings by Climate Zone. Almost 60 percent of the 17,376 units were in the Cold Climate Zone.

Table 3.6. PY 2008 WAP Weighted Housing Units in Large Multifamily Buildings by Climate Zone

\begin{tabular}{lcc} 
Climate Zone & PY 2008 Units & Percent of PY 2008 Units \\
\hline Very Cold Climate & 3,423 & $20 \%$ \\
Cold Climate & 10,125 & $58 \%$ \\
Moderate Climate & 1,301 & $7 \%$ \\
Hot/Humid Climate & 418 & $2 \%$ \\
Hot/Dry Climate & 2,109 & $12 \%$ \\
\hline TOTAL & 17,376 & $100 \%$ \\
\hline
\end{tabular}


Table 3.7 shows that 69 percent of all units in large multifamily buildings were reported by New York, Wisconsin, California, and Ohio.

Table 3.7. PY 2008 WAP Weighted Clients in Large

Multifamily Units by State

\begin{tabular}{lcc} 
State & PY 2008 Units & Percent of PY 2008 Units \\
\hline New York & 7,306 & $42 \%$ \\
Wisconsin & 1,950 & $11 \%$ \\
California & 1,579 & $9 \%$ \\
Ohio & 1,164 & $7 \%$ \\
All Other States & 5,377 & $31 \%$ \\
\hline TOTAL & 17,376 & $100 \%$ \\
\hline
\end{tabular}

Table 3.8 shows the distribution of large multifamily buildings by the number of units in the building and Table 3.9 shows the distribution of total weatherized units. Most of the large multifamily buildings treated in the program are reported to have 5 to 9 housing units; they represent 45 percent of all large multifamily buildings weatherized by the program. However, buildings with 25 or more units represented almost 60 percent of units weatherized in PY 2008.

Table 3.8. PY 2008 WAP Weighted Large Multifamily

Buildings by Number of Units in Building

\begin{tabular}{lcc} 
Building Type & Number of Buildings & Percent of Buildings \\
\hline Units Not Reported* & 273 & $23 \%$ \\
$5-9$ Units & 544 & $45 \%$ \\
10-24 Units & 228 & $19 \%$ \\
$25+$ Units & 163 & $13 \%$ \\
\hline TOTAL & 1,208 & $100 \%$ \\
\hline
\end{tabular}

* Note: Some grantees did not report the total units in the building.

Table 3.9. PY 2008 WAP Weighted Large Multifamily

Units by Number of Units in Building

\begin{tabular}{lcc} 
Building Type & Number of Units & Percent of Units \\
\hline Units Not Reported* & 410 & $2 \%$ \\
5-9 Units & 3,475 & $20 \%$ \\
10-24 Units & 3,572 & $21 \%$ \\
25+ Units & 9,919 & $57 \%$ \\
\hline TOTAL & 17,376 & $100 \%$ \\
\hline
\end{tabular}

* Note: Some grantees did not report the total units in the building. 


\subsection{BUILDING CHARACTERISTICS}

Table 3.10a furnishes national and Climate Zone statistics on the housing unit characteristics for PY 2008 large multifamily buildings treated by the program. The overall finding is that these housing units vary by Climate Zone. Large multifamily units in the Cold Climate Zone are the oldest. The average size of units in all zones is relatively small.

Table 3.10a. PY 2008 Large Multifamily Buildings Housing Unit Characteristics by Climate Zone

\begin{tabular}{|c|c|c|c|c|}
\hline Statistic & NATIONAL & $\begin{array}{c}\text { Very Cold } \\
\text { Climate }\end{array}$ & $\begin{array}{c}\text { Cold } \\
\text { Climate } \\
\end{array}$ & $\begin{array}{l}\text { Hot/Dry } \\
\text { Climate } \\
\end{array}$ \\
\hline \multicolumn{5}{|l|}{ Heated Space per Unit } \\
\hline Median & 816 & 768 & 825 & 675 \\
\hline Mean & 821 & 709 & 837 & 866 \\
\hline \multicolumn{5}{|l|}{ Building Vintage } \\
\hline$\%$ pre- 1940 & $27 \%$ & $22 \%$ & $32 \%$ & $0 \%$ \\
\hline \% 1940-1969 & $24 \%$ & $9 \%$ & $28 \%$ & $24 \%$ \\
\hline$\% 1970$ or later & $49 \%$ & $69 \%$ & $40 \%$ & $76 \%$ \\
\hline \multicolumn{5}{|l|}{ Weather } \\
\hline Mean HDD 65 & 5,417 & 6,924 & 5,779 & 2,244 \\
\hline Mean CDD 65 & 871 & 605 & 820 & 1,274 \\
\hline
\end{tabular}

Table 3.10b furnishes statistics on the housing unit characteristics for PY 2008 large multifamily buildings by the number of units in the dwelling and compares the statistics for the large multifamily buildings to those for single family homes. The overall finding is that there are no clear differences by the number of units in the building. However, on average, large multifamily buildings have smaller unit size and are newer than single family homes.

Table 3.10b. PY 2008 Large Multifamily Buildings Housing Unit Characteristics by Number of Units

\begin{tabular}{|c|c|c|c|c|c|}
\hline Statistic & $\begin{array}{c}\text { All } \\
\text { Buildings }\end{array}$ & $\begin{array}{l}\text { 5-9 Unit } \\
\text { Buildings }\end{array}$ & $\begin{array}{l}\text { 10-24 Unit } \\
\text { Buildings }\end{array}$ & $\begin{array}{l}\text { 25+ Unit } \\
\text { Buildings }\end{array}$ & $\begin{array}{c}\text { Single } \\
\text { Family } \\
\text { Homes }\end{array}$ \\
\hline \multicolumn{6}{|l|}{ Heated Space per Unit } \\
\hline Median & 816 & 776 & 804 & 872 & 1,272 \\
\hline Mean & 821 & 800 & 796 & 837 & 1,418 \\
\hline \multicolumn{6}{|l|}{ Building Vintage } \\
\hline$\%$ pre-1940 & $27 \%$ & $17 \%$ & $32 \%$ & $29 \%$ & $32 \%$ \\
\hline \% 1940-1969 & $24 \%$ & $16 \%$ & $45 \%$ & $23 \%$ & $43 \%$ \\
\hline$\% 1970$ or later & $49 \%$ & $67 \%$ & $23 \%$ & $48 \%$ & $26 \%$ \\
\hline \multicolumn{6}{|l|}{ Weather } \\
\hline Mean HDD 65 & 5,417 & 5,465 & 5,212 & 5,504 & 5,398 \\
\hline Mean CDD 65 & 871 & 892 & 754 & 888 & 1,042 \\
\hline
\end{tabular}

Table 3.11a furnishes national and Climate Zone statistics on the heating and cooling systems for PY 2008 large multifamily buildings. The overall finding is that large multifamily buildings treated by the 
WAP program in PY 2008 most often used gas heat, had central heating systems, and had window/wall air conditioning units. The characteristics of treated buildings varied substantially by Climate Zone; the Hot/Dry Climate Zone had a higher proportion of gas heat than did the other zones, and was most likely to have a wall or room heater.

Table 3.11a. PY 2008 Large Multifamily Buildings Heating and Cooling System Characteristics by Climate Zone

\begin{tabular}{|c|c|c|c|c|}
\hline Statistic & NATIONAL & $\begin{array}{l}\text { Very Cold } \\
\text { Climate }\end{array}$ & $\begin{array}{c}\text { Cold } \\
\text { Climate } \\
\end{array}$ & $\begin{array}{l}\text { Hot/Dry } \\
\text { Climate } \\
\end{array}$ \\
\hline \multicolumn{5}{|l|}{ Heating Fuel } \\
\hline$\%$ Natural Gas & $71 \%$ & $62 \%$ & $71 \%$ & $83 \%$ \\
\hline$\%$ Electric & $10 \%$ & $15 \%$ & $6 \%$ & $10 \%$ \\
\hline$\%$ Fuel Oil & $17 \%$ & $17 \%$ & $22 \%$ & $0 \%$ \\
\hline$\%$ Propane & $2 \%$ & $5 \%$ & $0 \%$ & $7 \%$ \\
\hline$\%$ Other & $1 \%$ & $0 \%$ & $1 \%$ & $0 \%$ \\
\hline \multicolumn{5}{|l|}{ Heating System Type } \\
\hline$\%$ Central Forced Air & $19 \%$ & $17 \%$ & $19 \%$ & $22 \%$ \\
\hline$\%$ Boiler (hydronic/steam) & $65 \%$ & $68 \%$ & $78 \%$ & $7 \%$ \\
\hline$\%$ Wall/Room Heater & $9 \%$ & $1 \%$ & $1 \%$ & $70 \%$ \\
\hline$\%$ Electric Baseboard & $5 \%$ & $15 \%$ & $2 \%$ & $<1 \%$ \\
\hline$\%$ Other or None & $2 \%$ & $0 \%$ & $<1 \%$ & $<1 \%$ \\
\hline \multicolumn{5}{|l|}{ Supplemental Heat } \\
\hline$\%$ Electric & $5 \%$ & $0 \%$ & $1 \%$ & $0 \%$ \\
\hline$\%$ Kerosene & $7 \%$ & $0 \%$ & $9 \%$ & $0 \%$ \\
\hline \multicolumn{5}{|l|}{ Air Conditioning Type } \\
\hline$\%$ Central AC & $13 \%$ & $15 \%$ & $6 \%$ & $19 \%$ \\
\hline$\%$ Window/Wall & $73 \%$ & $54 \%$ & $91 \%$ & $29 \%$ \\
\hline$\%$ None & $14 \%$ & $31 \%$ & $3 \%$ & $51 \%$ \\
\hline \multicolumn{5}{|l|}{ Water Heating Fuel } \\
\hline$\%$ Natural Gas & $68 \%$ & $52 \%$ & $71 \%$ & $82 \%$ \\
\hline$\%$ Electric & $11 \%$ & $17 \%$ & $5 \%$ & $10 \%$ \\
\hline$\%$ Fuel Oil & $13 \%$ & $24 \%$ & $15 \%$ & $0 \%$ \\
\hline$\%$ Propane & $2 \%$ & $7 \%$ & $1 \%$ & $8 \%$ \\
\hline
\end{tabular}

Table 3.11b furnishes national and Climate Zone statistics on the heating and cooling systems for PY 2008 large multifamily buildings by the number of units in the dwelling and compares the statistics for the large multifamily buildings to single family homes. The overall finding is that the largest buildings (25 or more units) are most likely to have hydronic or steam heating systems and window/wall air conditioners than do smaller buildings. Large multifamily buildings in general are more likely to have those heating and cooling systems than are single family homes. 
Table 3.11b. PY 2008 Large Multifamily Buildings

Heating and Cooling System Characteristics by Number of Units

\begin{tabular}{|c|c|c|c|c|c|}
\hline Statistic & $\begin{array}{c}\text { All Large } \\
\text { Multifamily } \\
\text { Buildings }\end{array}$ & $\begin{array}{l}\text { 5-9 Unit } \\
\text { Buildings }\end{array}$ & $\begin{array}{l}\text { 10-24 Unit } \\
\text { Buildings }\end{array}$ & $\begin{array}{l}\text { 25+ Unit } \\
\text { Buildings }\end{array}$ & $\begin{array}{l}\text { Single } \\
\text { Family } \\
\text { Homes }\end{array}$ \\
\hline \multicolumn{6}{|l|}{ Heating Fuel } \\
\hline$\%$ Natural Gas & $71 \%$ & $77 \%$ & $70 \%$ & $69 \%$ & $60 \%$ \\
\hline$\%$ Electric & $10 \%$ & $15 \%$ & $12 \%$ & $7 \%$ & $14 \%$ \\
\hline$\%$ Fuel Oil & $17 \%$ & $6 \%$ & $15 \%$ & $22 \%$ & $14 \%$ \\
\hline$\%$ Propane & $2 \%$ & $2 \%$ & $2 \%$ & $1 \%$ & $9 \%$ \\
\hline$\%$ Other & $1 \%$ & $0 \%$ & $0 \%$ & $1 \%$ & $3 \%$ \\
\hline \multicolumn{6}{|l|}{ Heating System Type } \\
\hline$\%$ Central Forced Air & $19 \%$ & $45 \%$ & $22 \%$ & $6 \%$ & $67 \%$ \\
\hline$\%$ Boiler (hydronic/steam) & $65 \%$ & $35 \%$ & $45 \%$ & $86 \%$ & $12 \%$ \\
\hline$\%$ Wall/Room Heater & $9 \%$ & $11 \%$ & $28 \%$ & $1 \%$ & $11 \%$ \\
\hline$\%$ Electric Baseboard & $5 \%$ & $9 \%$ & $4 \%$ & $4 \%$ & $4 \%$ \\
\hline$\%$ Other or None & $2 \%$ & $<1 \%$ & $1 \%$ & $3 \%$ & $2 \%$ \\
\hline \multicolumn{6}{|l|}{ Supplemental Heat } \\
\hline$\%$ Electric & $5 \%$ & $1 \%$ & $0 \%$ & $8 \%$ & $9 \%$ \\
\hline$\%$ Wood & $0 \%$ & $0 \%$ & $0 \%$ & $0 \%$ & $8 \%$ \\
\hline$\%$ Kerosene & $7 \%$ & $0 \%$ & $0 \%$ & $10 \%$ & $1 \%$ \\
\hline \multicolumn{6}{|l|}{ Air Conditioning Type } \\
\hline$\%$ Central AC & $13 \%$ & $13 \%$ & $14 \%$ & $10 \%$ & $39 \%$ \\
\hline$\%$ Window/Wall & $73 \%$ & $56 \%$ & $51 \%$ & $85 \%$ & $29 \%$ \\
\hline$\%$ None & $14 \%$ & $31 \%$ & $35 \%$ & $5 \%$ & $30 \%$ \\
\hline \multicolumn{6}{|l|}{ Water Heating Fuel } \\
\hline$\%$ Natural Gas & $68 \%$ & $73 \%$ & $72 \%$ & $64 \%$ & $55 \%$ \\
\hline$\%$ Electric & $11 \%$ & $19 \%$ & $6 \%$ & $9 \%$ & $35 \%$ \\
\hline$\%$ Fuel Oil & $13 \%$ & $6 \%$ & $3 \%$ & $20 \%$ & $4 \%$ \\
\hline$\%$ Propane & $2 \%$ & $2 \%$ & $4 \%$ & $2 \%$ & $6 \%$ \\
\hline
\end{tabular}

\subsection{ENERGY DIAGNOSTICS}

Table 3.12a shows the diagnostic approach used by subgrantees for the sample of homes treated in PY 2008 by Climate Zone. At the national level, 56 percent of large multifamily buildings were assessed using an audit tool while 44 percent were treated using a priority list. Weatherization Assistant was most often used in the Very Cold Zone while other audits (EA-QUIP or Treat) were most often used in the Cold Climate Zone. In the Hot/Dry Zone, all buildings were treated using a priority list. 
Table 3.12a. PY 2008 Clients in Large Multifamily Buildings

Diagnostics Approach by Climate Zone

\begin{tabular}{rcccc} 
Statistic & Very & $\begin{array}{c}\text { Cold } \\
\text { Climate }\end{array}$ & $\begin{array}{c}\text { Cold } \\
\text { Climate }\end{array}$ & $\begin{array}{c}\text { Hot/Dry } \\
\text { Zone }\end{array}$ \\
\hline $\begin{array}{r}\text { Diagnostic Approach } \\
\text { \% Weatherization Assistant }\end{array}$ & $6 \%$ & $15 \%$ & $4 \%$ & $0 \%$ \\
\% Targeted Investment Protocol System & $2 \%$ & $0 \%$ & $3 \%$ & $0 \%$ \\
$\%$ Other Audit & $54 \%$ & $14 \%$ & $71 \%$ & $0 \%$ \\
$\%$ Priority List & $36 \%$ & $58 \%$ & $21 \%$ & $100 \%$ \\
$\%$ Other & $2 \%$ & $13 \%$ & $1 \%$ & $0 \%$ \\
\hline
\end{tabular}

Table 3.12b shows the overall diagnostic approach used by subgrantees for the sample of homes treated in PY 2008 by number of units in the building. Buildings with 25 or more units used the EA-QUIP or Treat audit for more than three-fourths of the treated units. Buildings with fewer than 25 units most often had measures selected using a priority list. The distribution of audit type for single family homes was quite different from that for large multifamily buildings.

Table 3.12b. PY 2008 Clients in Large Multifamily Buildings Diagnostics Approach by Number of Units

\begin{tabular}{|c|c|c|c|c|c|c|}
\hline Statistic & & $\begin{array}{l}\text { All Large } \\
\text { Multifamily } \\
\text { Buildings }\end{array}$ & $\begin{array}{c}\text { 5-9 Unit } \\
\text { Buildings }\end{array}$ & $\begin{array}{l}\text { 10-24 Unit } \\
\text { Buildings }\end{array}$ & $\begin{array}{l}\text { 25+ Unit } \\
\text { Buildings } \\
\end{array}$ & $\begin{array}{c}\text { Single } \\
\text { Family } \\
\text { Homes }\end{array}$ \\
\hline \multicolumn{7}{|c|}{ Diagnostic Approach } \\
\hline & $\%$ Weatherization Assistant & $6 \%$ & $8 \%$ & $5 \%$ & $4 \%$ & $21 \%$ \\
\hline & $\%$ TIPS & $2 \%$ & $4 \%$ & $0 \%$ & $2 \%$ & $5 \%$ \\
\hline & $\%$ Other Audit & $54 \%$ & $13 \%$ & $37 \%$ & $78 \%$ & $15 \%$ \\
\hline & $\%$ Priority List & $36 \%$ & $75 \%$ & $58 \%$ & $13 \%$ & $56 \%$ \\
\hline & $\%$ Other & $2 \%$ & $1 \%$ & $0 \%$ & $3 \%$ & $3 \%$ \\
\hline
\end{tabular}

Table 3.13a shows the specific air leakage and heat loss diagnostics completed by subgrantees for the units treated in PY 2008 by Climate Zone. The findings include:

- Pressure Testing - Subgrantees reported that 20 percent of buildings received a blower door test. Zonal pressure tests were reported for fewer than 10 percent.

- Duct Testing - For almost 30 percent of buildings that had ducts, some form of duct leakage testing was conducted. Pressure pan tests were most common. However, few of these buildings have ducts (i.e., most have hydronic or steam systems or room heaters).

- IR Scanning - IR cameras were used for about one in ten weatherized units.

The highest rates of diagnostic testing were observed in the Cold Climate Zone. 
Table 3.13a. PY 2008 Clients in Large Multifamily Buildings Air Leakage and Insulation Diagnostics by Climate Zone

\begin{tabular}{ccccc} 
Statistic & NATIONAL & $\begin{array}{c}\text { Very Cold } \\
\text { Climate }\end{array}$ & $\begin{array}{c}\text { Cold } \\
\text { Climate }\end{array}$ & $\begin{array}{c}\text { Other } \\
\text { Zones }\end{array}$ \\
\hline Pressure Testing & & & & \\
$\%$ Blower Door & $18 \%$ & $30 \%$ & $16 \%$ & $5 \%$ \\
$\%$ Zonal Pressure & $7 \%$ & $1 \%$ & $10 \%$ & $0 \%$ \\
\% Room-to-Room Balance & $8 \%$ & $0 \%$ & $12 \%$ & $0 \%$ \\
\hline Duct Testing & & & & \\
(\% for units with ducts) & & & & \\
$\%$ Any Duct Test & $28 \%$ & $0 \%$ & $38 \%$ & $16 \%$ \\
$\%$ Pressure Pan & $22 \%$ & $0 \%$ & $37 \%$ & $0 \%$ \\
$\%$ Duct Blaster & $2 \%$ & $0 \%$ & $0 \%$ & $16 \%$ \\
\% Blower Door Subtraction & $5 \%$ & $0 \%$ & $1 \%$ & $0 \%$ \\
\hline Infrared Scanning & $13 \%$ & $13 \%$ & $16 \%$ & $0 \%$ \\
\hline
\end{tabular}

Table 3.13b shows the specific air leakage and heat loss diagnostics completed by subgrantees for the buildings treated in PY 2008 by number of units. The overall findings is that blower door testing and duct testing is most often conducted in the smaller buildings. Multifamily buildings are less likely to receive any type of pressure testing than are single family homes.

Table 3.13b. PY 2008 Clients in Large Multifamily Buildings Air Leakage and Insulation Diagnostics by Number of Units

\begin{tabular}{cccccc} 
Statistic & $\begin{array}{c}\text { All Large } \\
\text { Multifamily } \\
\text { Buildings }\end{array}$ & $\begin{array}{c}\text { 5-9 Unit } \\
\text { Buildings }\end{array}$ & $\begin{array}{c}\mathbf{1 0 - 2 4} \text { Unit } \\
\text { Buildings }\end{array}$ & $\begin{array}{c}\text { 25+ Unit } \\
\text { Buildings }\end{array}$ & $\begin{array}{c}\text { Single } \\
\text { Family } \\
\text { Homes }\end{array}$ \\
\hline Pressure Testing & & & & & \\
\% Blower Door & $18 \%$ & $41 \%$ & $21 \%$ & $8 \%$ & $87 \%$ \\
$\%$ Zonal Pressure & $7 \%$ & $11 \%$ & $11 \%$ & $4 \%$ & $29 \%$ \\
\% Room to Room Balance & $8 \%$ & $17 \%$ & $7 \%$ & $4 \%$ & $17 \%$ \\
\hline Duct Testing & & & & & \\
(\% for units with ducts) & & & & & \\
\% Any Duct Test & $28 \%$ & $35 \%$ & $46 \%$ & $14 \%$ & $25 \%$ \\
\% Pressure Pan & $22 \%$ & $31 \%$ & $46 \%$ & $0 \%$ & $22 \%$ \\
$\%$ Duct Blaster & $2 \%$ & $3 \%$ & $0 \%$ & $1 \%$ & $4 \%$ \\
\% Blower Door Subtraction & $5 \%$ & $1 \%$ & $0 \%$ & $13 \%$ & $6 \%$ \\
\hline Infrared Scanning & $13 \%$ & $19 \%$ & $13 \%$ & $12 \%$ & $19 \%$ \\
\hline
\end{tabular}

Table 3.14a shows the specific equipment testing completed by subgrantees for the buildings treated in PY 2008 by Climate Zone. Combustion equipment can be tested both for efficiency and for safety, while electric equipment can be tested for operating efficiency.

- Furnaces - Overall testing was conducted in about 68 percent of buildings nationally. Testing was much more common in the Cold Climate Zone. 
- Water Heaters - Sixty-three percent of water heaters had flue gas analysis; the highest rate was in the Cold Climate Zone where over three-fourths of buildings were tested. Water flow rates were tested for about three in ten buildings nationally with the highest testing rate reported in the Hot/Dry Climate Zone.

- Refrigerators - About four in ten refrigerators were metered nationwide. The highest rate was in the Cold Climate Zone where more than one-half of refrigerators were metered.

There is substantial variation in the number and types of diagnostic tests that are conducted; the variation by Climate Zone is significant.

Table 3.14a. PY 2008 Clients in Large Multifamily Buildings Equipment Diagnostics by Climate Zone

\begin{tabular}{lcccc} 
Statistic & NATIONAL & $\begin{array}{c}\text { Very Cold } \\
\text { Climate }\end{array}$ & $\begin{array}{c}\text { Cold } \\
\text { Climate }\end{array}$ & $\begin{array}{c}\text { Hot/Dry } \\
\text { Climate }\end{array}$ \\
\hline $\begin{array}{l}\text { Furnace Testing } \\
\text { \% for units applicable) }\end{array}$ & & & \\
\% Flue Gas Analysis & $68 \%$ & $32 \%$ & $86 \%$ & $60 \%$ \\
$\%$ Temperature Rise & $21 \%$ & $3 \%$ & $30 \%$ & $2 \%$ \\
$\%$ Thermostat Anticipator & $5 \%$ & $0 \%$ & $7 \%$ & $7 \%$ \\
\hline Water Heater Testing & & & & \\
(\% for units applicable) & & & & \\
$\%$ Flue Gas Analysis & $63 \%$ & $20 \%$ & $85 \%$ & $22 \%$ \\
$\%$ Hot Water Temperature & $57 \%$ & $7 \%$ & $82 \%$ & $14 \%$ \\
$\%$ Showerhead Flow Rate & $32 \%$ & $3 \%$ & $39 \%$ & $58 \%$ \\
$\%$ Faucet Flow Rate & $31 \%$ & $2 \%$ & $36 \%$ & $58 \%$ \\
\hline Refrigerator Usage Metering & $39 \%$ & $13 \%$ & $54 \%$ & $4 \%$ \\
\hline
\end{tabular}

Table 3.14b shows the specific equipment testing completed by subgrantees for the buildings treated in PY 2008 by number of units. The data show that testing rates for buildings with 25 or more units were higher than the rates for both smaller buildings and single family homes. 
Table 3.14b. PY 2008 Clients in Large Multifamily Buildings

Equipment Diagnostics by Number of Units

\begin{tabular}{lccccc} 
Statistic & $\begin{array}{c}\text { All Large } \\
\text { Multifamily } \\
\text { Buildings }\end{array}$ & $\begin{array}{c}\text { 5-9 Unit } \\
\text { Buildings }\end{array}$ & $\begin{array}{c}\mathbf{1 0 - 2 4} \text { Unit } \\
\text { Buildings }\end{array}$ & $\begin{array}{c}\text { 25+ Unit } \\
\text { Buildings }\end{array}$ & $\begin{array}{c}\text { Single } \\
\text { Family } \\
\text { Homes }\end{array}$ \\
\hline $\begin{array}{l}\text { Furnace Testing } \\
\text { (\% for units applicable) }\end{array}$ & & & & & \\
$\%$ Flue Gas Analysis & $68 \%$ & $54 \%$ & $56 \%$ & $77 \%$ & $59 \%$ \\
$\quad \%$ Temperature Rise & $21 \%$ & $32 \%$ & $14 \%$ & $20 \%$ & $31 \%$ \\
$\%$ Thermostat Anticipator & $5 \%$ & $17 \%$ & $7 \%$ & $1 \%$ & $10 \%$ \\
\hline Water Heater Testing & & & & & \\
(\% for units applicable) & & & & & \\
$\quad \%$ Flue Gas Analysis & $63 \%$ & $37 \%$ & $47 \%$ & $79 \%$ & $49 \%$ \\
$\%$ Hot Water Temperature & $57 \%$ & $35 \%$ & $39 \%$ & $72 \%$ & $39 \%$ \\
$\%$ Showerhead Flow Rate & $32 \%$ & $24 \%$ & $20 \%$ & $40 \%$ & $12 \%$ \\
$\%$ Faucet Flow Rate & $31 \%$ & $22 \%$ & $20 \%$ & $38 \%$ & $9 \%$ \\
\hline Refrigerator Usage Metering & $39 \%$ & $21 \%$ & $29 \%$ & $50 \%$ & $38 \%$ \\
\hline
\end{tabular}

\subsection{INSTALLED MEASURES}

Tables 3.15 to 3.18 furnish information on the rates at which different types of measures were installed in PY 2008.

Table 3.15a shows the rate at which air sealing and shell measures were installed in PY 2008 by Climate Zone.

- Air Sealing - Subgrantees reported that air sealing was completed in over 80 percent of buildings; bypass sealing using a blower door was reported for only one in five buildings, about the same percentage of buildings that got a blower door test. Air sealing using a blower door was reported at the highest rate in the Cold Climate Zone.

- Attic Insulation - Attic insulation was reported for a little over one-half of buildings. It was installed at the highest rate in the Very Cold Climate Zone.

- Wall Insulation - Very few buildings received wall insulation. About one in five buildings received wall insulation in the very Cold Climate Zone. But, in other zones it was rarely installed.

- Other Insulation - Floor, rim joist, and foundation insulation was installed at low rates, and only in the Very Cold and Cold Climate Zones.

Many large multifamily buildings received air sealing and attic insulation. Very few received wall insulation or other insulation. Installation rates varied considerable by Climate Zone. 
Table 3.15a. PY 2008 Clients in Large Multifamily Buildings Air Sealing and Shell Measures by Climate Zone

\begin{tabular}{ccccc} 
Statistic & & $\begin{array}{c}\text { Very } \\
\text { Cold } \\
\text { Climate }\end{array}$ & $\begin{array}{c}\text { Cold } \\
\text { Climate }\end{array}$ & $\begin{array}{c}\text { Hot/Dry } \\
\text { Climate }\end{array}$ \\
\hline $\begin{array}{c}\text { Air Sealing } \\
\text { Bypass Sealing w/Blower Door }\end{array}$ & $20 \%$ & $9 \%$ & $22 \%$ & $12 \%$ \\
Bypass Sealing w/o Blower Door & $46 \%$ & $47 \%$ & $51 \%$ & $51 \%$ \\
Caulking w/o Bypass Sealing & $15 \%$ & $42 \%$ & $7 \%$ & $32 \%$ \\
Any Bypass Sealing or Caulking & $81 \%$ & $98 \%$ & $79 \%$ & $95 \%$ \\
\hline Attic Insulation & & & & \\
$\%$ Installed (none existing) & $31 \%$ & $34 \%$ & $40 \%$ & $1 \%$ \\
$\%$ Installed (over existing) & $25 \%$ & $45 \%$ & $23 \%$ & $0 \%$ \\
$\%$ Installed (unknown) & $1 \%$ & $0 \%$ & $1 \%$ & $0 \%$ \\
$\%$ Installed (all types) & $57 \%$ & $78 \%$ & $64 \%$ & $1 \%$ \\
$\%$ & & & & \\
$\%$ Installed (regular) & $1 \%$ & $0 \%$ & $2 \%$ & $0 \%$ \\
$\%$ Installed (dense pack) & $6 \%$ & $20 \%$ & $2 \%$ & $0 \%$ \\
$\%$ Installed (all types) & $8 \%$ & $20 \%$ & $4 \%$ & $0 \%$ \\
\hline Wall Insulation Floor Insulation & $5 \%$ & $0 \%$ & $7 \%$ & $0 \%$ \\
$\%$ Foundation Insulation & $2 \%$ & $10 \%$ & $0 \%$ & $0 \%$ \\
\hline Other Insulation & & & & \\
\% Rim/band Joist Insulation & $3 \%$ & $9 \%$ & $2 \%$ & $0 \%$ \\
\hline
\end{tabular}

Table 3.15b shows the rate at which air sealing and shell measures were installed in PY 2008 by the number of units in the building. The buildings with 5 to 9 units were most likely to have blower doorguided air sealing, attic insulation, wall insulation, and other insulation. Installation rates for those buildings were similar to installation rates for single family homes. Installation rates for larger multifamily buildings were much lower. 
Table 3.15b. PY 2008 Clients in Large Multifamily Buildings

Air Sealing and Shell Measures by Number of Units

\begin{tabular}{|c|c|c|c|c|c|}
\hline Statistic & $\begin{array}{c}\text { All Large } \\
\text { Multifamily } \\
\text { Buildings }\end{array}$ & $\begin{array}{l}\text { 5-9 Unit } \\
\text { Buildings }\end{array}$ & $\begin{array}{c}\text { 10-24 Unit } \\
\text { Buildings }\end{array}$ & $\begin{array}{l}\text { 25+ Unit } \\
\text { Buildings }\end{array}$ & $\begin{array}{l}\text { Single } \\
\text { Family } \\
\text { Homes }\end{array}$ \\
\hline \multicolumn{6}{|l|}{ Air Sealing } \\
\hline Bypass Sealing w/Blower Door & $20 \%$ & $51 \%$ & $15 \%$ & $9 \%$ & $68 \%$ \\
\hline Bypass Sealing w/o Blower Door & $46 \%$ & $30 \%$ & $48 \%$ & $52 \%$ & $11 \%$ \\
\hline Caulking w/o Bypass Sealing & $15 \%$ & $12 \%$ & $20 \%$ & $15 \%$ & $13 \%$ \\
\hline Any Bypass Sealing or Caulking & $81 \%$ & $93 \%$ & $82 \%$ & $76 \%$ & $92 \%$ \\
\hline \multicolumn{6}{|l|}{ Attic Insulation } \\
\hline$\%$ Installed (none existing) & $31 \%$ & $20 \%$ & $28 \%$ & $37 \%$ & $26 \%$ \\
\hline$\%$ Installed (over existing) & $25 \%$ & $47 \%$ & $27 \%$ & $16 \%$ & $38 \%$ \\
\hline$\%$ Installed (unknown) & $1 \%$ & $3 \%$ & $1 \%$ & $0 \%$ & $6 \%$ \\
\hline$\%$ Installed (all types) & $57 \%$ & $71 \%$ & $57 \%$ & $53 \%$ & $70 \%$ \\
\hline \multicolumn{6}{|l|}{ Wall Insulation } \\
\hline$\%$ Installed (regular) & $1 \%$ & $1 \%$ & $1 \%$ & $2 \%$ & $8 \%$ \\
\hline$\%$ Installed (dense pack) & $6 \%$ & $10 \%$ & $2 \%$ & $6 \%$ & $21 \%$ \\
\hline$\%$ Installed (all types) & $8 \%$ & $11 \%$ & $3 \%$ & $9 \%$ & $29 \%$ \\
\hline \multicolumn{6}{|l|}{ Other Insulation } \\
\hline$\%$ Floor Insulation & $5 \%$ & $15 \%$ & $1 \%$ & $2 \%$ & $15 \%$ \\
\hline$\%$ Rim/band Joist Insulation & $3 \%$ & $10 \%$ & $2 \%$ & $1 \%$ & $17 \%$ \\
\hline$\%$ Foundation Insulation & $2 \%$ & $5 \%$ & $3 \%$ & $0 \%$ & $4 \%$ \\
\hline
\end{tabular}

Table 3.16a shows the rate at which equipment measures were installed in PY 2008 by Climate Zone. The key findings include:

- Heating Equipment - Heating equipment replacement was reported for about 38 percent of buildings, with most characterized as an energy conservation measure (ECM) and the rest characterized as primarily for health and safety. Overall, one-half of the buildings had some heating system work completed. Equipment replacement rates were much higher in the Very Cold and Cold Climate Zones than in the other areas.

- Ducts - Duct sealing was reported in about four in ten buildings that had ducts. But, since most buildings have hydronic, steam, or room heating equipment and window-wall air conditioners, very few buildings had ducts. Very few buildings had duct insulation.

- Water Heating Equipment - About one in five buildings had water heater equipment replacement; in most cases it was considered to be an energy conservation measure. Replacement rates were highest in the Very Cold and Cold Climate Zones. 
- $\quad$ Other Water Measures - The most common other water measures were showerheads and faucet aerators. In addition, more than one-half of the buildings in the Very Cold Climate Zone received pipe wrap.

Equipment measures in large multifamily buildings are less common than are air sealing and insulation. But, most of the equipment replacement measures are considered to be energy conservation measures. For single family homes and mobile homes, most of the heating, water heating, and cooling equipment replacements were considered to be health and safety measures.

Table 3.16a. PY 2008 Clients in Large Multifamily Buildings Heating and Water Heating Equipment Measures by Climate Zone

\begin{tabular}{rcccc} 
Statistic & NATIONAL & $\begin{array}{c}\text { Very Cold } \\
\text { Climate }\end{array}$ & $\begin{array}{c}\text { Cold } \\
\text { Climate }\end{array}$ & $\begin{array}{c}\text { Hot/Dry } \\
\text { Climate }\end{array}$ \\
\hline Heating Equipment & & & & \\
New Furnace (ECM) & $33 \%$ & $41 \%$ & $40 \%$ & $9 \%$ \\
New Furnace (non-ECM) & $5 \%$ & $0 \%$ & $7 \%$ & $0 \%$ \\
Heating System Tune-up & $9 \%$ & $15 \%$ & $11 \%$ & $0 \%$ \\
Other Heating System Repairs & $5 \%$ & $3 \%$ & $7 \%$ & $3 \%$ \\
Any Heating System Measure & $53 \%$ & $59 \%$ & $64 \%$ & $12 \%$ \\
\hline Heating Ducts & & & & \\
(\% of systems with ducts) & & & & \\
Duct Sealing & $42 \%$ & $77 \%$ & $42 \%$ & $22 \%$ \\
Duct Insulation & $5 \%$ & $0 \%$ & $7 \%$ & $0 \%$ \\
\hline Water Heating Equipment & & & & \\
New Water Heater (ECM) & $20 \%$ & $23 \%$ & $26 \%$ & $0 \%$ \\
New Water Heater (non-ECM) & $2 \%$ & $10 \%$ & $1 \%$ & $0 \%$ \\
Water Heater Repair & $1 \%$ & $0 \%$ & $2 \%$ & $0 \%$ \\
\hline Water Measures & & & & \\
Temperature Reduction & $11 \%$ & $1 \%$ & $17 \%$ & $2 \%$ \\
Showerhead & $53 \%$ & $46 \%$ & $64 \%$ & $44 \%$ \\
Faucet Aerator & $37 \%$ & $50 \%$ & $31 \%$ & $80 \%$ \\
\hline
\end{tabular}

Table 3.16b shows the rate at which equipment measures were installed in PY 2008 by number of units in the building and for single family homes. The table shows that heating equipment and water heating equipment were replaced at much higher rates in the largest buildings. Showerheads and faucet aerators were most common in the largest buildings, while smaller buildings were most likely to have pipe wrap and temperature reduction. Equipment replacement rates in large multifamily buildings were much higher than in single family homes. 
Table 3.16b. PY 2008 Clients in Large Multifamily Buildings Heating and Water Heating Equipment Measures by Number of Units

\begin{tabular}{|c|c|c|c|c|c|}
\hline Statistic & $\begin{array}{l}\text { All Large } \\
\text { Multifamily } \\
\text { Buildings } \\
\end{array}$ & $\begin{array}{l}\text { 5-9 Unit } \\
\text { Buildings }\end{array}$ & $\begin{array}{l}\text { 10-24 Unit } \\
\text { Buildings }\end{array}$ & $\begin{array}{l}\text { 25+ Unit } \\
\text { Buildings }\end{array}$ & $\begin{array}{l}\text { Single } \\
\text { Family } \\
\text { Homes }\end{array}$ \\
\hline \multicolumn{6}{|l|}{ Heating Equipment } \\
\hline New Furnace (ECM) & $33 \%$ & $17 \%$ & $19 \%$ & $44 \%$ & $12 \%$ \\
\hline New Furnace (non-ECM) & $5 \%$ & $6 \%$ & $9 \%$ & $4 \%$ & $10 \%$ \\
\hline Heating System Tune-up & $9 \%$ & $21 \%$ & $13 \%$ & $4 \%$ & $18 \%$ \\
\hline Other Heating System Repairs & $5 \%$ & $14 \%$ & $1 \%$ & $4 \%$ & $4 \%$ \\
\hline Programmable Thermostat & $<1 \%$ & $1 \%$ & $0 \%$ & $0 \%$ & $2 \%$ \\
\hline Any Heating System Measure & $53 \%$ & $58 \%$ & $42 \%$ & $55 \%$ & $48 \%$ \\
\hline \multicolumn{6}{|l|}{$\begin{array}{l}\text { Heating Ducts } \\
\text { (\% of systems with ducts) }\end{array}$} \\
\hline Duct Sealing & $42 \%$ & $36 \%$ & $85 \%$ & $0 \%$ & $42 \%$ \\
\hline Duct Insulation & $5 \%$ & $10 \%$ & $0 \%$ & $0 \%$ & $3 \%$ \\
\hline \multicolumn{6}{|l|}{ Water Heating Equipment } \\
\hline New Water Heater (ECM) & $20 \%$ & $8 \%$ & $16 \%$ & $26 \%$ & $3 \%$ \\
\hline New Water Heater (non-ECM) & $2 \%$ & $0 \%$ & $8 \%$ & $1 \%$ & $6 \%$ \\
\hline Water Heater Repair & $1 \%$ & $7 \%$ & $0 \%$ & $0 \%$ & $8 \%$ \\
\hline \multicolumn{6}{|l|}{ Water Measures } \\
\hline Tank Wrap & $8 \%$ & $20 \%$ & $19 \%$ & $1 \%$ & $26 \%$ \\
\hline Pipe Wrap & $29 \%$ & $37 \%$ & $41 \%$ & $22 \%$ & $44 \%$ \\
\hline Temperature Reduction & $11 \%$ & $19 \%$ & $16 \%$ & $7 \%$ & $9 \%$ \\
\hline Showerhead & $53 \%$ & $36 \%$ & $48 \%$ & $61 \%$ & $22 \%$ \\
\hline Faucet Aerator & $37 \%$ & $26 \%$ & $58 \%$ & $34 \%$ & $22 \%$ \\
\hline
\end{tabular}

Table 3.17a shows the rate at which door and window measures were installed in PY 2008 by Climate Zone. The statistics show that about 36 percent of units had new windows that were considered to be energy conservation measures, as opposed to health and safety measures, and 14 percent of units had new doors that were considered to be energy conservation measures. Installation rates for windows were much higher in the Cold Climate Zone than in any other zone. 
Table 3.17a. PY 2008 Clients in Large Multifamily Buildings

Door and Window Measures by Climate Zone

\begin{tabular}{rcccc}
\multicolumn{1}{l}{ Statistic } & NATIONAL & $\begin{array}{c}\text { Very } \\
\text { Cold } \\
\text { Climate }\end{array}$ & $\begin{array}{c}\text { Cold } \\
\text { Climate }\end{array}$ & $\begin{array}{c}\text { Hot/Dry } \\
\text { Climate }\end{array}$ \\
\hline \multicolumn{1}{l}{ Windows } & & & & \\
New Window (ECM) & $36 \%$ & $6 \%$ & $47 \%$ & $2 \%$ \\
New Window (non-ECM) & $2 \%$ & $0 \%$ & $3 \%$ & $0 \%$ \\
Storm Window & $1 \%$ & $0 \%$ & $0 \%$ & $0 \%$ \\
Window Glazing & $<1 \%$ & $0 \%$ & $<1 \%$ & $0 \%$ \\
Other Window Repair & $6 \%$ & $6 \%$ & $8 \%$ & $1 \%$ \\
Any Window Measure & $46 \%$ & $13 \%$ & $68 \%$ & $3 \%$ \\
Doors & & & & \\
New Door (ECM) & $14 \%$ & $0 \%$ & $11 \%$ & $22 \%$ \\
New Door (non-ECM) & $1 \%$ & $0 \%$ & $1 \%$ & $0 \%$ \\
Storm Door & $<1 \%$ & $0 \%$ & $<1 \%$ & $0 \%$ \\
Door Repair & $1 \%$ & $0 \%$ & $1 \%$ & $3 \%$ \\
Other Door Measure & $6 \%$ & $9 \%$ & $8 \%$ & $0 \%$ \\
Any Door Measure & $22 \%$ & $9 \%$ & $20 \%$ & $26 \%$ \\
\hline
\end{tabular}

Table 3.17b shows the rate at which door and window measures were installed in PY 2008 by number of units and for single family homes. The table shows that the largest buildings had the highest installation rates for windows and doors, and that the installation rates were much higher than for single family homes. 
Table 3.17b. PY 2008 Clients in Large Multifamily Buildings

Door and Window Measures by Number of Units

\begin{tabular}{rccccc}
\multicolumn{1}{l}{ Statistic } & $\begin{array}{c}\text { All Large } \\
\text { Multifamily } \\
\text { Buildings }\end{array}$ & $\begin{array}{c}\mathbf{5 - 9} \text { Unit } \\
\text { Buildings }\end{array}$ & $\begin{array}{c}\text { 10-24 Unit } \\
\text { Buildings }\end{array}$ & $\begin{array}{c}\text { 25+ Unit } \\
\text { Buildings }\end{array}$ & $\begin{array}{c}\text { Single } \\
\text { Family } \\
\text { Homes }\end{array}$ \\
\hline \multicolumn{1}{l}{ Windows } & & & & & \\
New Window (ECM) & $36 \%$ & $9 \%$ & $18 \%$ & $53 \%$ & $11 \%$ \\
New Window (non-ECM) & $2 \%$ & $0 \%$ & $3 \%$ & $3 \%$ & $6 \%$ \\
Storm Window & $1 \%$ & $0 \%$ & $0 \%$ & $3 \%$ & $3 \%$ \\
Window Glazing & $<1 \%$ & $<1 \%$ & $<1 \%$ & $0 \%$ & $8 \%$ \\
Other Window Repair & $6 \%$ & $10 \%$ & $2 \%$ & $6 \%$ & $9 \%$ \\
Any Window Measure & $46 \%$ & $20 \%$ & $23 \%$ & $65 \%$ & $37 \%$ \\
\hline Noors & & & & & $11 \%$ \\
New Door (ECM) & $14 \%$ & $11 \%$ & $7 \%$ & $19 \%$ & $7 \%$ \\
New Door (non-ECM) & $1 \%$ & $<1 \%$ & $<1 \%$ & $1 \%$ & $<1 \%$ \\
Storm Door & $<1 \%$ & $1 \%$ & $0 \%$ & $0 \%$ & $9 \%$ \\
Other Door Measure & $6 \%$ & $6 \%$ & $11 \%$ & $5 \%$ & $13 \%$ \\
Any Door Measure & $22 \%$ & $21 \%$ & $18 \%$ & $24 \%$ & $40 \%$ \\
\hline
\end{tabular}

Table 3.18a shows the rate at which electric base load equipment measures were installed in PY 2008 by Climate Zone.

- Lighting Measures - Over 80 percent of units in large multifamily buildings received some form of energy efficient lighting. Over 95 percent of homes in the Hot/Dry Zone received lighting measures.

- Refrigerators - Over four in ten units in large multifamily buildings received a new refrigerator. Over one-half of units in the Very Cold Climate Zone had a refrigerator installed.

These statistics show that the WAP program made investments in electric lighting and refrigerators and is likely to yield electric base load savings in addition to the energy savings for heating and water heating. For tenants of multifamily buildings where heat is included in the rent, these base load electric savings are likely to have the greatest short-run impact on affordability. 
Table 3.18a. PY 2008 Clients in Large Multifamily Buildings

Electric Base Load Equipment Measures by Climate Zone

\begin{tabular}{rcccc} 
Statistic & NATIONAL & $\begin{array}{c}\text { Very } \\
\text { Cold } \\
\text { Climate }\end{array}$ & $\begin{array}{c}\text { Cold } \\
\text { Climate }\end{array}$ & $\begin{array}{c}\text { Hot/Dry } \\
\text { Climate }\end{array}$ \\
\hline Other Electric Measures & & & & \\
Lighting (inside or outside) & $81 \%$ & $90 \%$ & $83 \%$ & $95 \%$ \\
Refrigerator (ECM) & $42 \%$ & $57 \%$ & $48 \%$ & $3 \%$ \\
Refrigerator (non-ECM) & $2 \%$ & $2 \%$ & $3 \%$ & $0 \%$ \\
Freezer & $0 \%$ & $0 \%$ & $0 \%$ & $0 \%$ \\
Other Base Load Measures & $5 \%$ & $0 \%$ & $2 \%$ & $14 \%$ \\
\hline
\end{tabular}

Table $3.18 \mathrm{~b}$ shows the rate at which electric base load equipment measures were installed in PY 2008 by number of units and for single family homes. The installation rate of measures was highest for the largest buildings. Installation rates for units in large multifamily buildings were much higher than those for single family homes.

Table 3.18b. PY 2008 Clients in Large Multifamily Buildings Electric Base Load Equipment Measures by Number of Units

\begin{tabular}{rccccc} 
Statistic & $\begin{array}{c}\text { All Large } \\
\text { Multifamily } \\
\text { Buildings }\end{array}$ & $\begin{array}{c}\text { 5-9 Unit } \\
\text { Buildings }\end{array}$ & $\begin{array}{c}\mathbf{1 0 - 2 4} \text { Unit } \\
\text { Buildings }\end{array}$ & $\begin{array}{c}\text { 25+ Unit } \\
\text { Buildings }\end{array}$ & $\begin{array}{c}\text { Fingle } \\
\text { Family } \\
\text { Homes }\end{array}$ \\
\hline Other Electric Measures & & & & & \\
Lighting (inside or outside) & $81 \%$ & $62 \%$ & $85 \%$ & $86 \%$ & $63 \%$ \\
Refrigerator (ECM) & $42 \%$ & $25 \%$ & $41 \%$ & $50 \%$ & $12 \%$ \\
Refrigerator (non-ECM) & $2 \%$ & $0 \%$ & $1 \%$ & $4 \%$ & $1 \%$ \\
Freezer & $0 \%$ & $0 \%$ & $0 \%$ & $0 \%$ & $2 \%$ \\
Other Base Load Measures & $5 \%$ & $2 \%$ & $8 \%$ & $4 \%$ & $4 \%$ \\
\hline
\end{tabular}




\section{ENERGY USAGE IMPACTS}

The evaluation team collected electric and gas data for the national sample of large multifamily buildings. In addition, the evaluation team conducted a special study of large multifamily buildings in New York City (NYC) and collected building-level gas, electric, and fuel oil data, as well as both electric data for individual housing units. Those data were used to examine the changes in energy consumption for large multifamily buildings and, to the extent possible, project the energy savings for all weatherized units.

The energy usage impact analysis was segmented into two groups - the non-NYC national sample and the NYC sample. The primary reason for approaching the analysis in this way was that the program weatherized, for the most part, different types of building in the two geographic areas.

- Non-NYC National Sample - Outside the New York City area, a significant share of the large multifamily buildings weatherized by the program in PY 2008 had unit-level, rather than building-level, heating and water heating equipment. As such, the usage data collection and analysis was for individual units, rather than for master-meter building-level accounts. In addition, for a significant share of the weatherized units outside New York City, the individual unit was weatherized rather than the whole building.

- $\quad$ NYC Sample - In the New York City area, most of the large multifamily buildings weatherized by the WAP program had centralized systems for heating and water heating, as well as significant common area (i.e., lobbies, hallways, and stairways) electric loads. Most of the buildings weatherized by the program in NYC received both building-level measures (e.g., heating and water heating systems, roof insulation, and windows) and unit-level measures (e.g., refrigerators, CFLs, and sealing around air conditioners).

This section of the report presents the findings for each population segment (i.e., non-NYC national sample and NYC sample) with respect to energy usage impacts, including measured energy savings for the buildings with usage data, an analysis of energy savings factors, and projected energy savings for the population of large multifamily buildings.

A report drafted by ORNL entitled Weatherization Works ${ }^{6}$ includes a summary of energy impacts for all housing types as well as information on cost-effectiveness and nonenergy impacts.

\subsection{METHODOLOGY}

Natural gas and electric usage data were collected for the national sample of large multifamily buildings that are heated with natural gas or electricity. Using these data the primary analysis approach was a standard pre/post treatment/comparison design using weather normalized utility billing data. The weathernormalization approach employed was similar to PRISM $^{7}$ and produces estimates of weather-adjusted annual energy consumption for each building or unit based on monthly usage data and daily outdoor temperatures using a variable degree day base regression analysis. For these buildings, the analysis examined both the net and gross impacts.

- Gross Savings - Gross energy savings for each building or unit were calculated as the difference in the normalized annual consumption between the pre-treatment and post-treatment periods.

\footnotetext{
${ }^{6}$ Tonn et al. 2014. Weatherization Works - Summary of Findings from the Retrospective Evaluation of the U.S. Department of Energy's Weatherization Assistance Program. ORNL/TM-2014/338, Oak Ridge National Laboratory, Oak Ridge, Tennessee. National Laboratory, Oak Ridge, TN.

${ }^{7}$ See "PRISM: An Introduction," Margaret Fels, Energy and Buildings 9, \#1-2, pp. 5-18 (1986).
} 
- Net Savings - A comparison group of untreated buildings and units also was analyzed to reflect changes in usage which may have occurred without the program. The comparison group was created using later participants - large multifamily buildings and units treated in PY 2009 were used as a comparison group for the PY 2008 analysis. Comparison group usage was analyzed by subtracting one year from the actual treatment date to create pseudo pre-treatment and posttreatment periods after removing actual post-treatment usage data. Net program savings were then calculated as the average gross savings for participants minus the average savings (i.e., change in usage) found for the comparison group.

Energy usage data were also collected for the supplemental sample of large multifamily buildings in New York City. The evaluation team sent staff to the NYC agencies to collect all energy account information, including building-level natural gas and fuel oil accounts, building-level common area electric accounts, and unit-level electric accounts. For each of those types of data, the evaluation team conducted the following analyses.

- $\quad$ PRISM Type Building-/Unit-Level Analysis - For each building and unit, each account with sufficient pre/post usage data received a PRISM type analysis that produces estimates of weatheradjusted annual energy consumption for each account based on monthly usage data and daily outdoor temperatures using a variable degree day base regression analysis.

- Factors Analysis - The results of the weather normalization analysis were also summarized in a variety of ways to address research questions and were further explored using statistical models to estimate savings by measure and the relationship between observed savings and other factors.

Since the treatment group was all large multifamily buildings weatherized in New York State in 2007, 2008, and 2009, there was no comparison group available to estimate net impacts. So, the usage impact results for the NYC supplemental sample represent gross effects only.

\subsection{ENERGY SAVINGS - NON-NYC NATIONAL SAMPLE}

Table 4.1 summarizes natural gas impacts for the national sample of large multifamily buildings outside NYC with gas main heat. The overall gas savings are estimated at 81 therms $^{8}$ per year per unit, equal to $8.4 \%$ of pre-program gas usage.

Table 4.1. PY 2008 WAP Energy Impacts for Large Multifamily Buildings - Non-NYC Sample Gross and Net Gas Savings Per Unit for Gas Main Heat (therms/unit/year)

\begin{tabular}{|c|c|c|c|c|c|c|c|}
\hline Group & $\begin{array}{l}\text { \# of Units } \\
\text { in } \\
\text { Buildings }\end{array}$ & $\begin{array}{c}\text { \# of } \\
\text { Accounts }\end{array}$ & $\begin{array}{c}\text { Gas Use } \\
\text { Pre-WAP }\end{array}$ & $\begin{array}{c}\text { Gas Use } \\
\text { Post- } \\
\text { WAP }\end{array}$ & $\begin{array}{c}\text { Gross } \\
\text { Savings }\end{array}$ & $\begin{array}{c}\text { Net } \\
\text { Savings }\end{array}$ & $\%$ of Pre \\
\hline Treatment & 1,327 & 94 & 903 & 822 & 81 & \multirow{2}{*}{$76( \pm 36)$} & \multirow{2}{*}{$\begin{array}{c}8.4 \% \\
( \pm 3.9 \%)\end{array}$} \\
\hline Comparison & 356 & 44 & 739 & 734 & 5 & & \\
\hline
\end{tabular}

There are some important analytic problems with the findings presented in Table 4.1. It was difficult to get account numbers for both individual and master meter accounts for large multifamily buildings. As a result, the 94 accounts in the analysis are from a total of only 31 buildings, including 91 individually metered accounts from 28 buildings and master-meter accounts for three buildings with 96 total weatherized units. In addition, the accounts are from just eight states and 60 percent of the accounts are

\footnotetext{
${ }^{8}$ 100,000 British Thermal Units
} 
from a single state. Given these issues, it is not clear how reliable a picture of national savings for large multifamily buildings outside NYC can be developed from these data. Finally, since the comparison group of accounts is both small (44 accounts) and clearly different from the treatment group ( 739 therms average pre-use compared to 903 therms) the gross to net savings adjustment also is unreliable.

Table 4.2 summarizes electric impacts overall and by end use among gas-heated buildings in the national non-NYC sample. For these units, the average net savings were estimated at $275 \mathrm{kWh}$ per year (7.4\%) but these savings were not statistically different from zero.

Table 4.2. PY 2008 WAP Energy Impacts for Large Multifamily Buildings - Non-NYC Sample Gross and Net Electric Savings Per Unit for Natural Gas Main Heat (kWh/unit/year)

\begin{tabular}{lccccccc} 
& $\begin{array}{c}\text { \# Units } \\
\text { in }\end{array}$ & $\begin{array}{c}\text { \# of } \\
\text { Accounts }\end{array}$ & $\begin{array}{c}\text { Electric } \\
\text { Use Pre- } \\
\text { WAP }\end{array}$ & $\begin{array}{c}\text { Electric } \\
\text { Use Post- } \\
\text { WAP }\end{array}$ & $\begin{array}{c}\text { Gross } \\
\text { Savings }\end{array}$ & $\begin{array}{c}\text { Net } \\
\text { Savings }\end{array}$ & \% of Pre \\
\hline Treatment & 1,471 & 118 & 3,709 & 3,504 & 205 & & $7.4 \%$ \\
Comparison & 138 & 36 & 5,868 & 5,938 & -70 & & $( \pm 378)$ \\
\hline
\end{tabular}

Table 4.3 summarizes electric impacts for the national sample of large multifamily buildings outside NYC with electric main heat. The overall electric savings are estimated at $4,951 \mathrm{kWh}$ per year per unit, equal to $32.1 \%$ of pre-program gas usage. These savings are higher in value and percent than the gross savings of $1,995 \mathrm{kWh}$ found in site built homes.

Table 4.3. PY 2008 WAP Energy Impacts for Large Multifamily Buildings - Non-NYC Sample Gross Electric Savings Per Unit for Electric Main Heat (kWh/unit/year)

\begin{tabular}{lccccccc} 
& $\begin{array}{c}\text { \# of Units } \\
\text { in } \\
\text { Buildings }\end{array}$ & $\begin{array}{c}\text { \# of } \\
\text { Accounts }\end{array}$ & $\begin{array}{c}\text { Gas Use } \\
\text { Pre-WAP }\end{array}$ & $\begin{array}{c}\text { Gas Use } \\
\text { Post- } \\
\text { WAP }\end{array}$ & $\begin{array}{c}\text { Gross } \\
\text { Savings }\end{array}$ & $\begin{array}{c}\text { Net } \\
\text { Savings }\end{array}$ & \% of Pre \\
\hline Treatment & 393 & 68 & 15,401 & 10,450 & 4,951 & n/a & $\begin{array}{c}32.1 \% \\
( \pm 7.8 \%)\end{array}$ \\
\hline
\end{tabular}

Overall, the data available for the analysis of energy savings for large multifamily buildings treated by the weatherization program outside New York City are not sufficient to furnish estimates of program savings, to investigate the factors that are associated with different levels of energy savings, or to assess the program cost-effectiveness.

\subsection{ENERGY SAVING - NYC SAMPLE}

Table 4.4 summarizes gas and fuel oil usage impacts for the national sample of large multifamily buildings weatherized in NYC during PY 2007, 2008, and 2009. The gas savings are estimated at 82 therms per unit per year, equal to $12.5 \%$ of pre-program gas usage. The fuel oil savings are estimated at 234 therms per unit per year, equal to $24.0 \%$ of pre-program fuel oil usage. The difference between the natural gas and fuel oil savings are statistically significant and are likely to result from the higher level of energy savings opportunities associated with higher pre-weatherization usage; usage per unit for buildings heated with fuel oil is about 50 percent higher than for buildings heated with natural gas. In addition, only one-third of gas-heated buildings got boiler replacements while over two-thirds of the buildings heated with fuel oil had boiler replacements. 
Table 4.4. PY 2007-2009 WAP Energy Impacts for Large Multifamily Buildings - NYC Sample Gross Gas and Oil Savings (therms/unit/year)

\begin{tabular}{lccccccc} 
Group & $\begin{array}{c}\text { \# of Units } \\
\text { in } \\
\text { Buildings }\end{array}$ & $\begin{array}{c}\text { \# of } \\
\text { Accounts }\end{array}$ & $\begin{array}{c}\text { Fuel Use } \\
\text { Pre-WAP }\end{array}$ & $\begin{array}{c}\text { Fuel Use } \\
\text { Post- } \\
\text { WAP }\end{array}$ & $\begin{array}{c}\text { Gross } \\
\text { Savings }\end{array}$ & $\begin{array}{c}\text { Net } \\
\text { Savings }\end{array}$ & \% of Pre \\
\hline Gas Heat & 3,764 & 65 & 656 & 574 & 82 & n/a & $12.5 \%( \pm 4.2 \%)$ \\
Oil Heat & 1,738 & 41 & 973 & 739 & 234 & n/a & $24.0 \%( \pm 7.2 \%)$ \\
\hline
\end{tabular}

Table 4.5 summarizes electric impacts overall and by end use among the NYC sample buildings. For these units, the average net savings were estimated at $172 \mathrm{kWh}(6.7 \%)$ per unit per year for common areas and $816 \mathrm{kWh}(23.2 \%)$ per unit per year. In NYC, the WAP program replaced refrigerators in about twothirds of the units and did lighting retrofits in about half of the units. These high measure installation rates are likely to be responsible for the large observed savings. Adding in the common area savings, the total electric savings is $988 \mathrm{kWh}$ per year per unit (16.3\%).

Table 4.5. PY 2007-2009 WAP Energy Impacts for Large Multifamily Buildings - NYC Sample Gross Electric Savings (kWh/unit/year)

\begin{tabular}{lcccccc}
$\begin{array}{l}\text { Usage } \\
\text { Component }\end{array}$ & $\begin{array}{c}\text { \# of } \\
\text { Accounts }\end{array}$ & $\begin{array}{c}\text { Electric } \\
\text { Use Pre- } \\
\text { WAP }\end{array}$ & $\begin{array}{c}\text { Electric } \\
\text { Use Post- } \\
\text { WAP }\end{array}$ & $\begin{array}{c}\text { Gross } \\
\text { Savings }\end{array}$ & $\begin{array}{c}\text { Net } \\
\text { Savings }\end{array}$ & \% of Pre \\
\hline Common Area & 147 & 2,557 & 2,385 & 172 & $\mathrm{n} / \mathrm{a}$ & $6.7 \%$ \\
Apartment Units & 251 & 3,513 & 2,697 & 816 & $\mathrm{n} / \mathrm{a}$ & $23.2 \%$ \\
\hline
\end{tabular}

\subsection{PROJECTED PY 2008 ENERGY SAVINGS FOR LARGE MULTIFAMILY BUILDINGS}

The overall goal of the evaluation is to project total energy savings and energy savings per unit for the PY 2008 WAP program. While the measured savings statistics furnish valuable information, they do not furnish direct estimates for the WAP population. For other building types, where larger sample sizes were available for analysis, a series of analysis procedures was used to develop savings estimates for the population of households served by the WAP program. However, for large multifamily buildings, where sample sizes are much smaller, a different set of procedures was applied.

\subsubsection{Projected Energy Savings for The National Non-NYC Sample}

Energy saving results for the national non-NYC sample of large multifamily buildings are presented in Tables 4.1 (natural gas savings), 4.2 (electric base load savings), and 4.3 (electric heat savings). However, each of those statistics is based on a small and potentially biased sample, and there is no adequate comparison group that would allow the estimation of a gross to net savings adjustment. For that reason, it is not appropriate to project WAP energy savings for PY 2008 from that analysis.

\subsubsection{Projected Energy Savings for the NYC Sample}

In the New York City sample, the number of buildings for which energy impacts could be estimated was relatively large compared to the overall population; there were 223 eligible buildings for PY 2007-2009 and saving estimates were available for 106 buildings (48\%). Using the buildings with savings, the 
evaluation team developed a simple energy savings model to project gas, fuel oil, and electric savings for all PY 2008 buildings.

- Main Heat Savings - A two-factor energy savings model was developed that looked at whether buildings got boiler replacements and insulation. Those models were estimated and applied separately for gas heated and oil heated buildings.

- Electric Base Load - A one-factor model was developed that looked at whether a unit got a refrigerator or not.

Table 4.6 summarizes the large multifamily estimates of savings by heating fuel for the buildings treated by NYC agencies. These savings estimates are used in the cost savings and cost-effectiveness analyses presented in Section 5.

Table 4.6. PY 2008 WAP Energy Impacts for Large Multifamily Buildings - NYC Sample Projected Fuel and Electric Savings per Unit, by Heating Fuel

\begin{tabular}{lccc} 
Heating Fuel & \# Units & $\begin{array}{c}\text { Fuel Savings } \\
\text { (therms/unit/y } \\
\text { ear) }\end{array}$ & $\begin{array}{c}\text { Electric Savings } \\
\text { (kWh/unit/year) }\end{array}$ \\
\hline Natural Gas & 3,425 & 124 & 943 \\
Oil & 1,919 & 235 & 881 \\
\hline All Fuels & 5,344 & 164 & 921 \\
\hline
\end{tabular}





\section{COST SAVINGS, MEASURE COSTS, AND COST-EFFECTIVENESS}

The WAP evaluation assessed program cost-effectiveness along multiple dimensions that are related to the various goals of the program and how resources are allocated. Some of the main issues in this analysis include:

- Energy Savings - The evaluation developed estimates of the first year energy savings from the program and used the estimated life of individual measures to project total energy savings over time.

- Energy Cost Savings - The evaluation is using data on current energy prices and price projections to estimate the cost savings associated with the projected energy savings.

- Nonenergy Benefits - The evaluation is collecting data and referencing literature sources to estimate and monetize nonenergy benefits associated with service delivery.

- Service Delivery Costs - The evaluation collected information from agencies to assess the service delivery costs for each building, including breakouts of energy efficiency measures, health and safety measures, and home repairs.

- Total Program Costs - The evaluation collected information from DOE, states, and agencies to document program administration and training costs.

- Cost-Effectiveness - Program cost-effectiveness has been computed from multiple perspectives that assess the benefits and costs in terms of both energy and nonenergy aspects of the program.

The analysis here focuses narrowly on two elements of cost-effectiveness: the cost to install measures meant to save energy (and incidental repairs that enable their installation) and the value of the energy savings from those measures. The measure of cost-effectiveness reported here excludes costs for health and safety measures and indirect program costs, as well as nonenergy benefits from the program.

\subsection{COST SAVINGS AND COST-EFFECTIVENESS FOR NON-NYC SAMPLE}

The evaluation was able to collect good quality data on building characteristics, installed measures, and measure costs for the units in large multifamily buildings that were treated by the program in PY 2008. However, as discussed in Section 4, the energy usage data were inadequate to develop an estimate of energy savings for the population of buildings outside New York City. So, no final estimates of program cost-effectiveness can be developed for this population of treated buildings.

\subsection{COST SAVINGS AND COST-EFFECTIVENESS FOR NYC SAMPLE}

The evaluation was able to collect comprehensive data for the sample of NYC buildings, including building characteristics, installed measures, measure costs, and energy savings for the units in large multifamily buildings that were treated by the program in PYs 2007-2009. This part of the report uses those data to document the installation costs by source and measure, the cost savings associated with energy usage reduction, and the cost-effectiveness of the program for large multifamily buildings in New York City.

The program cost data available for NYC buildings documented the sources and uses of the funds used for weatherizing buildings. The primary sources of funding for weatherization of large multifamily buildings were WAP funds, contributions from the building owner, and resources from other programs. 
The primary uses of funding for weatherization of large multifamily buildings were efficiency measures, health and safety measures, and building repair.

Table 5.1 furnishes statistics for these cost and funding categories. These data show that the WAP program covered 57 percent of costs, compared to 25 percent for the building owner and 18 percent for other programs. In terms of measure categories, about 86 percent of the funding was used for efficiency measures, about 3 percent for health and safety measures, and about 11 percent of repairs. Almost all of the WAP funding was for efficiency measures, while almost 30 percent of the spending by the building owner was for repairs.

Table 5.1. Spending on Large Multifamily Buildings for PYs 2007-2009 - NYC Sample

by Funding Source and Measure Category

\begin{tabular}{|l|c|c|c|c|c|c|c|c|}
\hline \multirow{2}{*}{$\begin{array}{l}\text { Measure } \\
\text { Category }\end{array}$} & \multicolumn{2}{|c|}{ WAP } & \multicolumn{2}{c|}{ Owner } & \multicolumn{2}{c|}{ Other Programs } & \multicolumn{2}{c|}{ Total } \\
\cline { 2 - 9 } & $\begin{array}{c}\text { Average } \\
\text { Spending }\end{array}$ & $\begin{array}{c}\text { Percent of } \\
\text { Spending }\end{array}$ & $\begin{array}{c}\text { Average } \\
\text { Spending }\end{array}$ & $\begin{array}{c}\text { Percent of } \\
\text { Spending }\end{array}$ & $\begin{array}{c}\text { Average } \\
\text { Spending }\end{array}$ & $\begin{array}{c}\text { Percent of } \\
\text { Spending }\end{array}$ & $\begin{array}{c}\text { Average } \\
\text { Spending }\end{array}$ & $\begin{array}{c}\text { Percent of } \\
\text { Spending }\end{array}$ \\
\hline Efficiency & $\$ 2,270$ & $96 \%$ & $\$ 676$ & $65 \%$ & $\$ 627$ & $83 \%$ & $\$ 3,572$ & $86 \%$ \\
\hline Health/Safety & $\$ 61$ & $3 \%$ & $\$ 69$ & $7 \%$ & $\$ 12$ & $1 \%$ & $\$ 142$ & $3 \%$ \\
\hline Repair & $\$ 34$ & $1 \%$ & $\$ 294$ & $28 \%$ & $\$ 119$ & $16 \%$ & $\$ 447$ & $11 \%$ \\
\hline Total & $\$ 2,365$ & $100 \%$ & $\$ 1,039$ & $100 \%$ & $\$ 758$ & $100 \%$ & $\$ 4,161$ & $100 \%$ \\
\hline Funding \% & \multicolumn{3}{|c|}{$57 \%$} & \multicolumn{2}{|c|}{$25 \%$} & \multicolumn{2}{|c|}{$18 \%$} & \multicolumn{2}{|c|}{$100 \%$} \\
\hline
\end{tabular}

Table 5.2 furnishes more detail on the spending for specific energy efficiency measures. The table shows that two measures - window/door replacement and boiler replacement - account for about two-thirds of all spending. The distribution of spending by measure is similar for WAP and for building owners. Other funding sources spend a lower percentage on window/door replacement and a higher percentage on boiler replacement, refrigerators, and facility lighting.

Table 5.2. Spending on Large Multifamily Buildings for PYs 2007-2009 - NYC Sample

by Funding Source and Energy Efficiency Measure

\begin{tabular}{|c|c|c|c|c|c|c|c|c|}
\hline \multirow[b]{2}{*}{$\begin{array}{l}\text { Measure } \\
\text { Category }\end{array}$} & \multicolumn{2}{|c|}{ WAP } & \multicolumn{2}{|c|}{ Owner } & \multicolumn{2}{|c|}{ Other Programs } & \multicolumn{2}{|c|}{ Total } \\
\hline & $\begin{array}{c}\text { Average } \\
\text { Spending }\end{array}$ & $\begin{array}{c}\text { Percent of } \\
\text { Spending }\end{array}$ & $\begin{array}{c}\text { Average } \\
\text { Spending }\end{array}$ & $\begin{array}{l}\text { Percent of } \\
\text { Spending }\end{array}$ & $\begin{array}{c}\text { Average } \\
\text { Spending }\end{array}$ & $\begin{array}{c}\text { Percent of } \\
\text { Spending }\end{array}$ & $\begin{array}{c}\text { Average } \\
\text { Spending }\end{array}$ & $\begin{array}{l}\text { Percent of } \\
\text { Spending }\end{array}$ \\
\hline Windows/Doors & $\$ 972$ & $43 \%$ & $\$ 290$ & $43 \%$ & $\$ 201$ & $32 \%$ & $\$ 1,463$ & $41 \%$ \\
\hline Boilers & $\$ 536$ & $24 \%$ & $\$ 153$ & $23 \%$ & $\$ 177$ & $28 \%$ & $\$ 866$ & $24 \%$ \\
\hline $\begin{array}{l}\text { Facility } \\
\text { Lighting }\end{array}$ & $\$ 323$ & $14 \%$ & $\$ 68$ & $10 \%$ & $\$ 99$ & $16 \%$ & $\$ 491$ & $14 \%$ \\
\hline Other Heating & $\$ 173$ & $8 \%$ & $\$ 77$ & $11 \%$ & $\$ 41$ & $7 \%$ & $\$ 291$ & $8 \%$ \\
\hline Refrigerators & $\$ 89$ & $4 \%$ & $\$ 24$ & $4 \%$ & $\$ 59$ & $9 \%$ & $\$ 172$ & $5 \%$ \\
\hline Insulation & $\$ 84$ & $4 \%$ & $\$ 4$ & $1 \%$ & $\$ 13$ & $2 \%$ & $\$ 101$ & $3 \%$ \\
\hline Unit Lighting & $\$ 57$ & $3 \%$ & $\$ 12$ & $2 \%$ & $\$ 29$ & $5 \%$ & $\$ 98$ & $3 \%$ \\
\hline Water Heating & $\$ 27$ & $1 \%$ & $\$ 14$ & $2 \%$ & $\$ 2$ & $0 \%$ & $\$ 44$ & $1 \%$ \\
\hline Air Sealing & $\$ 9$ & $0 \%$ & $\$ 32$ & $5 \%$ & $\$ 6$ & $1 \%$ & $\$ 47$ & $1 \%$ \\
\hline Total & $\$ 2,270$ & $100 \%$ & $\$ 676$ & $100 \%$ & $\$ 627$ & $100 \%$ & $\$ 3,572$ & $100 \%$ \\
\hline
\end{tabular}


Tables 5.3a through 5.3c furnish estimates of the cost savings and cost-effectiveness for the NYC PY 2008 large multifamily buildings. Since the population of large multifamily buildings has higher levels of leveraged spending than other building types, the installed measures in the buildings are only partially a function of the guidelines established by the WAP program. To gain a more complete understanding of both cost-effectiveness with respect to WAP funds and leveraged funds, three different sets of costs are examined in this analysis.

- WAP Funding - The lower limit on expenditures analysis shows cost-effectiveness ratios if only WAP expenditures are included in the analysis. In this analysis, the overall energy efficiency SIR for the NYC buildings in PY 2008 was 2.99; it was 1.27 for gas heated buildings and 4.64 for fuel oil heated buildings. (Table 5.3a)

- All Sources of Funding - The upper limit on expenditures analysis shows cost-effectiveness ratios if all expenditures sources are included in the analysis. In this analysis, the overall energy efficiency SIR for the NYC buildings in PY 2008 was 1.82; it was 0.80 for gas heated buildings and 3.10 for fuel oil heated buildings. (Table 5.3b)

- All Sources Excluding non-WAP Windows/Doors - The mid-range for expenditures included all funding sources except for windows and doors paid for by non-WAP sources. Under this scenario, the overall energy efficiency SIR was 2.10; it was 0.94 for gas heated buildings and 3.56 for fuel oil heated buildings. (Table 5.3c)

For all three scenarios, the overall energy efficiency savings-to-investment ratio (SIR) for large multifamily buildings treated by the WAP program by New York City agencies was cost-effective. However, the program services delivered to buildings with fuel oil main heat had significantly higher savings-to-investment ratios because those buildings had higher energy savings and the average price per unit for fuel oil was much higher than the price for natural gas.

Table 5.3a. PY 2008 WAP Impacts for Large Multifamily Buildings - NYC Sample Energy Cost Savings, Efficiency Measure Costs, and Cost-Effectiveness

\section{Measures Funded by WAP}

Energy Cost Savings (present value of lifetime savings)
Costs \& Cost-Effectiveness

\begin{tabular}{lcc|c|cccc}
\cline { 2 - 6 } Heating Fuel & Fuel & Electric & Total & $\begin{array}{c}\text { Measure } \\
\text { Costs }\end{array}$ & $\begin{array}{c}\text { Net } \\
\text { Benefits }\end{array}$ & $\begin{array}{c}\text { Savings/ } \\
\text { Investment } \\
\text { Ratio }\end{array}$ & $\begin{array}{c}\text { SIR 90\% } \\
\text { c.i. }\end{array}$ \\
\hline Natural Gas & $\$ 1,203$ & $\$ 1,207$ & $\$ 2,410$ & $\$ 1,899$ & $\$ 511$ & 1.27 & $0.77-1.88$ \\
Fuel Oil & $\$ 10,926$ & $\$ 1,241$ & $\$ 11,537$ & $\$ 2,485$ & $\$ 9,052$ & 4.64 & $3.04-6.87$ \\
\hline All Clients & $\$ \mathbf{5 , 2 3 7}$ & $\mathbf{\$ 1 , 2 2 2}$ & $\mathbf{\$ 6 , 4 5 9}$ & $\mathbf{\$ 2 , 1 5 9}$ & $\mathbf{\$ 4 , 3 0 0}$ & $\mathbf{2 . 9 9}$ & \\
\hline
\end{tabular}


Table 5.3b. PY 2008 WAP Impacts for Large Multifamily Buildings - NYC Sample Energy Cost Savings, Efficiency Measure Costs, and Cost-Effectiveness

Measures Funded by All Sources

Energy Cost Savings (present value of lifetime savings)

Costs \& Cost-Effectiveness

\begin{tabular}{|c|c|c|c|c|c|c|c|}
\hline Heating Fuel & Fuel & Electric & Total & $\begin{array}{c}\text { Measure } \\
\text { Costs }\end{array}$ & $\begin{array}{c}\text { Net } \\
\text { Benefits }\end{array}$ & $\begin{array}{c}\text { Savings/ } \\
\text { Investment } \\
\text { Ratio }\end{array}$ & $\begin{array}{c}\text { SIR 90\% } \\
\text { c.i. }\end{array}$ \\
\hline Natural Gas & $\$ 1,203$ & $\$ 1,207$ & $\$ 2,410$ & $\$ 3,029$ & $(\$ 619)$ & 0.80 & $0.48-1.17$ \\
\hline Fuel Oil & $\$ 10,926$ & $\$ 1,241$ & $\$ 11,537$ & $\$ 3,721$ & $\$ 7,816$ & 3.10 & $2.04-4.59$ \\
\hline All Clients & $\$ 5,237$ & $\$ 1,222$ & $\$ 6,459$ & $\$ 3,336$ & $\$ 3,123$ & 1.94 & \\
\hline
\end{tabular}

Table 5.3c. PY 2008 WAP Impacts for Large Multifamily Buildings - NYC Sample Energy Cost Savings, Efficiency Measure Costs, and Cost-Effectiveness

Measures Funded by All Sources (Exclude non-WAP Windows and Doors)

Energy Cost Savings

(present value of lifetime savings)

Costs \& Cost-Effectiveness

\begin{tabular}{lcc|c|cccc} 
& \multicolumn{3}{c}{} & & & \multicolumn{4}{c}{ Costs \& Cost-Effectiveness } \\
\cline { 2 - 8 } Heating Fuel & Fuel & Electric & Total & $\begin{array}{c}\text { Measure } \\
\text { Costs }\end{array}$ & $\begin{array}{c}\text { Net } \\
\text { Benefits }\end{array}$ & $\begin{array}{c}\text { Investment } \\
\text { Ratio }\end{array}$ & $\begin{array}{c}\text { SIR 90\% } \\
\text { c.i. }\end{array}$ \\
\hline Natural Gas & $\$ 1,203$ & $\$ 1,207$ & $\$ 2,410$ & $\$ 2,573$ & $(\$ 163)$ & 0.94 & $0.57-1.37$ \\
Fuel Oil & $\$ 10,926$ & $\$ 1,241$ & $\$ 11,537$ & $\$ 3,243$ & $\$ 8,294$ & 3.56 & $2.32-5.33$ \\
\hline All Clients & $\mathbf{\$ 5 , 2 3 7}$ & $\mathbf{\$ 1 , 2 2 2}$ & $\mathbf{\$ 6 , 4 5 9}$ & $\mathbf{\$ 2 , 8 7 0}$ & $\mathbf{\$ 3 , 5 8 9}$ & $\mathbf{2 . 2 5}$ & \\
\hline
\end{tabular}

